\title{
DNA methylation of repeated elements and cancer-related genes in normal human liver, and in cancer and non-cancer liver cell lines, treated with 5adC or PCB126
}

\author{
D. Desaulniers*, G.-H. Xiao, C. Cummings-Lorbetskie, L. Stubbert and C. Parfett \\ Health Canada, Environmental Health Science and Research Bureau, 50 Colombine Driveway, \\ AL 0803D Tunney’s Pasture, Ottawa, Ontario, K1A 0K9, Canada.
}

\begin{abstract}
DNA methylation is an important epigenetic mechanism contributing to the regulation of gene expression and to the stability of DNA repeated sequences. Abnormal DNA methylation is a characteristic of cancer cells and there are scientific concerns that exposure to environmental contaminants (EC) might contribute to carcinogenesis by altering DNA methylation mechanisms. This study compared DNA methylation of repeated elements and cancerrelated genes in normal human liver, and in cancer (HepG2) and non-cancer (HC-04) cell lines, and investigated the effects of 5-aza-2'-deoxycytidine (5adC; a demethylation control) and polychlorinated biphenyl-126 (PCB126), a non-genotoxic rodent hepatocarcinogen. The results revealed striking celltype differences in DNA methylation of repeated elements (AluYb8, LINE-1, Sat-alpha) and 7/9 cancerrelated genes (CCND2, DAB2IP, DLEC1, GSTp1, OPCML, RASSF1, RUNX3, but not SFRP2 and SOCS1). In 72-h dose-response experiments, 5adC induced " $U$ " shape demethylation responses in the nine investigated genes, but associated with elevated mRNA expression only in 6/9 and 3/9 genes in HC-04 and HepG2 cells, respectively. DNA methylation was resistant to PCB126 in most genes in both cell lines, except for reduced promoter methylation and increased expression of GSTp1 in HepG2 cells, which further support a role for oxidative stress in PCB126induced oncogenesis/toxicity. Finally, the different
\end{abstract}

\footnotetext{
*Corresponding author: daniel.desaulniers@canada.ca
}

DNA methylation patterns and gene expression responses between the non-cancer HC-04 and cancer HepG2 cell lines provide alternative models to further explore epigenetic divergence in gene expression regulation.

KEYWORDS: DNA methylation, HepG2, HC-04, liver, polychlorinated biphenyls, GSTp1

\section{ABBREVIATIONS}

CCND2, Cyclin D2; CDH1, Cadherin 1; CDKN1A, Cyclin-dependent kinase inhibitor 1A; CDKN1B, Cyclin-dependent kinase inhibitor 1B; CDKN2A, Cyclin-dependent kinase inhibitor 2A; DAB2IP, DAB2 interacting protein; DLC1, Deleted in liver cancer 1; DLEC1, Deleted in lung and esophageal cancer 1; E2F1, E2F transcription factor 1; EP300, E1A binding protein p300; FHIT, Fragile histidine triad gene; GSTp1, Glutathione S-transferase $\pi 1$; MSH2, MutS homolog 2; MSH3, MutS homolog 3; OPCML, Opioid binding protein/cell adhesion molecule-like; PYCARD, PYD and CARD domain containing; RASSF1, Ras association RalGDS/AF-6 domain family member 1; RUNX3, Reelin RELN; Runt-related transcription factor 3; SFRP2, Secreted frizzled-related protein 2; SOCS1, Suppressor of cytokine signaling 1; TNFRSF10D, Tumor necrosis factor receptor superfamily, member 10d; WT1, Wilms tumor 1.

\section{INTRODUCTION}

Abnormal DNA methylation [gain (hyper) and loss (hypo)] occurring early during carcinogenesis 
contributes to genome instability [1-3] and deregulation of gene expression [4]. DNA hypermethylation silences expression of tumor suppressor genes while hypomethylation can generate genome instability by increasing oncogene expression, activating retrotransposons, and altering centromere and kinetochore assembly [5].

DNA repeated elements are major components of the genome and include retrotransposons and structural elements. Long (LINEs) and short (SINEs) interspersed nuclear elements are families of retrotransposons inhibited by DNA methylation [6]. LINE-1 (L1) and AluYb8 (both investigated here) are examples of LINEs and SINEs. Retrotransposition events contribute to numerous diseases and cancers in multiple ways: (1) they affect genome integrity through recombination involving insertions, deletions, and rearrangements, (2) they introduce tandem repeats that are hypermutable sites, and (3) they provide alternative promoters and new splice sites inducing transcriptional and co-transcriptional splicing misregulation, expression of abnormal genes, and production of interfering chimeric transcripts [7-9]. Other DNA repeats can have structural roles and be located at specific chromosomal regions such as centromeric Satellite-alpha, juxtacentromeric NBL-2, and subtelomeric D4Z4 [3, 10]. Hypomethylation of structural DNA repeats is associated with chromosomal instability [11-13] and development of lymphomas [14].

An increasing number of reviews [15-18] and original investigations demonstrate changes in DNA methylation in repeated sequences and gene promoters associated with exposure to environmental contaminants (EC) such as organochlorine pesticides, polychlorinated biphenyls (PCB) [19, 20], polybrominated diphenyl ethers [21], obesogenic endocrine disrupters [22], heavy metals (arsenic, iron, nickel, cadmium) $[17,23,24]$, and with certain behavior such as smoking [25]. Although some chemical induced-changes in DNA methylation are transient, others are more permanent [26, 27], and support consideration to improve chemical risk assessments.

PCBs are a family of ubiquitous and persistent EC historically used mostly as heat resistant fluid in electrical transformers, and are known to alter numerous biological functions [28]. Polychlorinated dibenzodioxins (PCDD), polychlorinated dibenzofurans (PCDF) and PCB found in the environment still represent a human health risk [29, 30]. PCB126 (3,3',4,4',5-pentachlorobiphenyl), the PCB congener with the highest affinity for the aryl-hydrocarbon receptor (AhR), is non-genotoxic but acts as an animal liver tumor promoter [31], and in contrast to other legacy EC it showed no decline over time in human blood [32]. The toxicity of mixtures of AhR-agonists (PCDD, PCDF, dioxinlike PCB including PCB126) is expressed using a toxic equivalency system which is based on toxicity similarities (target organs and endpoints) and additive response among these chemicals [33, 34]. Therefore, testing PCB126 can be informative as a simplified surrogate for AhR-mixtures.

The objectives of the current experiments were to characterize DNA methylation differences in repeated sequences and in cancer-related genes between normal liver DNA and two human liver cell lines, and to explore if short term (72 h) exposure to PCB126 could induce changes in DNA methylation within these genes. The liver is the major detoxification organ where chemicals are transformed into metabolites to facilitate their excretion. Consequently, the liver is one of the most frequent chemical targets for induction of cancers [35], either through the initial EC exposure or through an intermediate toxic metabolite. Therefore, hepatocytes with metabolic activity were chosen for this work. The HepG2 cell line was derived from a hepatocarcinoma and was selected as a data-rich well-studied cancer cell line. The HC-04 cell line, more recently emerging in the literature, was established from liver tissues surrounding a hepatoma [36] and was selected as a non-cancer cell line. The DNA from each cell line was compared to DNA from normal human livers obtained commercially or from primary hepatocytes. DNA methylation was characterized by investigating DNA repeated elements (L1, AluYb8, D4Z4, Sat- $\alpha$, NBL-2) and nine known liver cancer-related genes (CCND2, DAB2IP, DLEC1, GSTp1, OPCML, RASSF1, RUNX3, SFRP2, SOCS1). In addition to PCB126, chemical treatments included exposure to two positive controls using the classic hypomethylating drug 5-aza-2'-deoxycytidine (5adC) [37], and a nonnucleoside quinolone molecule, SGI-1027, reported to induce DNA hypomethylation [38]. 


\section{MATERIALS AND METHODS}

\subsection{Reagents, hepatocyte DNA, cell lines, cell culture, and treatments}

PCB126 (3,3',4,4',5-pentachlorobiphenyl) and PCB153 (2,2',4,4',5,5'-hexachlorobiphenyl) were purchased from Wellington Laboratories (Guelph, ON, Canada) and Chromatographic Specialties (Brockville, ON, Canada), while 5-aza-2'deoxycytidine and SGI-1027 were from SigmaAldrich (St-Louis, MO, USA) and EMD Millipore (Burlington, ON, Canada), respectively.

Of the five normal human hepatocyte genomic DNA samples, the first was purchased as purified DNA (57 year old woman, cat\# D1234149, lot\#B105060; BioChain Institute Inc, Hayward, CA, USA), and the remaining four samples as cryopreserved hepatocytes (women with normal livers, Cat\# F00995, lot\# VLS age 34; lot\# CLM age 52, lot\# HPM age 34, lot\# KFM age 46; Celsis, Baltimore, MD, USA) from which genomic DNA was purified using the DNEasy blood and tissue kit (Qiagen, Toronto, ON, Canada).

The HC-04 cell line was selected because it was reported to have maintained numerous inducible Phase-I, -II, and III enzymes [39]. The HC-04 cell line (available from Biodefense and Emerging Infections Research Resources Repository, Manassas, VA, USA) is a spontaneously immortalized hepatocyte cell line that was established from liver tissues surrounding a hepatoma in a male patient. Morphologically, HC-04 cells resemble liver parenchymal cells and proliferate with a doubling time of approximately $24 \mathrm{~h}$. The HC-04 cells exhibit a hyperdiploid karyotype (range 47-50) with consistent abnormality on chromosome 1 [t(1;21)], 6 [del(6q)], and 15 [8der(15)] [36]. The HepG2 cell line [American Type Culture Collection (ATCC), Manassas, VA; Cat\#HB-8065] was established from a 15-year-old Caucasian male. It has a hyperdiploid karyotype (range 50-60) with rearranged chromosome 1 and was reported by ATCC to demonstrate cytogenetic instability. Our experiments with the HC-04 cell line were conducted from passages 56 to 73, and from passages 91 to 107 for the HepG2 cells.

HC-04 cells were cultured in Hepatocyte Basal Medium $\left(\mathrm{HBM}^{\mathrm{TM}}\right)$, supplemented with SingleQuots ${ }^{\mathrm{TM}}$ Hepatocyte Culture Media (HCM) growth factor kit [which includes ascorbic acid, BSA-fatty acid free, hydrocortisone, transferrin, insulin, rhEGF, gentamicin sulfate and amphothericin-B, at concentrations proprietary to Lonza (Walkersville, MD, USA)], and $10 \%$ fetal bovine serum (FBS) (Invitrogen, Burlington, ON, Canada). Fibronectin, bovine serum albumin fraction $\mathrm{V}$ (BSA), collagen $\mathrm{I}$, and dimethylsulfoxide (DMSO, sterile tissue culture grade) were from Sigma, whereas the trypsin $(0.25 \%$ solution), Dulbecco's modified phosphate buffered saline (D-PBS), Dulbecco's modified Eagle medium (DMEM), penicillin/streptomycin (Pen/Strep) and L-glutamine were obtained from Gibco/Invitrogen (Burlington, ON, Canada). Corning cell culture dishes, $100 \mathrm{~mm}$ and 96-well black culture plates for fluorescence, were purchased from VWR (Mississauga, ON, Canada).

The HepG2 cells were maintained in DMEM supplemented with $10 \%$ FBS, Pen/Strep $(100 \mathrm{U} / \mathrm{mL}$, $100 \mu \mathrm{g} / \mathrm{mL}$ ) and $2 \mathrm{mM}$ L-glutamine (Invitrogen). The HC-04 cells were grown as described by Lim et al. [39] in pre-coated culture flasks which involves incubating the flasks for $2 \mathrm{~h}\left(37^{\circ} \mathrm{C}, 5 \%\right.$ $\mathrm{CO}_{2}$ ) with $\mathrm{HBM}$ containing BSA, fibronectin $(0.01 \mathrm{mg} / \mathrm{mL}$ each), and collagen $(0.03 \mathrm{mg} / \mathrm{mL})$. The coating media was removed and the flasks were rinsed with D-PBS prior to seeding. The HC-04 cells were maintained in HBM medium supplemented with $10 \%$ FBS and the SingleQuots ${ }^{\mathrm{TM}}$ kit. Both cell lines were maintained in $100 \mathrm{~mm}$ culture dishes at $37{ }^{\circ} \mathrm{C}, 5 \% \mathrm{CO}_{2}, 100 \%$ humidity, and were fed every three to four days. Cultures were split at a $1: 3$ ratio once the cells had reached approximately 80\% confluency. 5adC and PCB126 were dissolved in domethylsulfoxide (DMSO) and tested at a final 0.5\% DMSO concentration. SGI-1027 was tested at a final $0.125 \%$ DMSO concentration.

\subsection{Proliferation assay}

Cells were seeded $(20,000$ per well in $100 \mu \mathrm{L})$ the day before treatment using black optical bottom 96-well culture plates (Corning Corp., Corning, NY, USA). On the day of treatment, the media was removed and replaced with the experimental medium containing increasing concentrations of test chemicals: up to $1 \mathrm{mM} 5 \mathrm{adC}$, and up to $150 \mu \mathrm{M}$ PCB126. After a $72 \mathrm{~h}$ incubation, an index of cellular abundance was obtained using the alamarBlue ${ }^{\circledR}$ assay according to the manufacturer's protocol (Gibco/Invitrogen, Burlington, ON, Canada), and as previously validated in our lab [40]. AlamarBlue fluorescence was 
measured using excitation/emission wavelengths of 560/590 nm on a Biotek Synergy-2 multi-mode microplate reader (Fisher Scientific, Ottawa, ON, Canada). Usually, 8 wells per concentration were considered (one column on a 96-well plate) for the analyses, but sometimes wells with abnormal results were eliminated based on the outlier Dixon's Q-test [41]. A minimum of three independent experiments were conducted per chemical.

\subsection{Gene selection}

The authors hypothesised that genes matching the following three criteria would be relevant DNA methylation targets potentially sensitive to the effects of EC. As a first criterion, the targets had to be relevant to liver carcinogenesis showing different methylation profiles in normal liver, the non-cancer HC-04 cells, and the cancer HepG2 cell line. A second criterion was selecting DNA methylation targets labile to 5adC treatment. It was assumed that genes whose DNA methylation levels respond to 5 adC are less likely to be simultaneously regulated by multiple epigenetic marks and mechanisms (e.g. histone modifications, non-coding RNA). A third criterion was that the target should show 5adC-induced changes in DNA methylation that could be biologically relevant as demonstrated by changes in mRNA expression.

The Methyl-Profiler DNA Methylation PCR Array System for liver cancer genes (\#335211, SABioscience/Qiagen), a restriction enzyme-based system, was initially used as a screening tool to identify a list of genes that could be differentially methylated across cell types and be sensitive to 5adC. This array interrogates DNA methylation abundance in 150 to 400 bp DNA segments located in CpG islands that flank promoter regions of 24 genes (CCND2, CDH1, CDKN1A, CDKN1B, CDKN2A, DAB2IP, DLC1, DLEC1, E2F1, EP300, FHIT, GSTp1, hsa-miR-1, MSH2, MSH3, OPCML, PYCARD, RASSF1, RELN, RUNX3, SFRP2, SOCS1, TNFRSF10D, and WT1) known to be differentially methylated in liver cancers (User Manual, SABiosciences, Part \#1038A, Version 2.3, $9 / 13 / 2010$ ). The assay principle [42] is based on realtime polymerase chain reaction (PCR) quantification of DNA template remaining following digestion with methyl sensitive and insensitive restriction enzymes provided in the kit and that are proprietary to SABiosciences/Qiagen. The assay was conducted by following the manufacturer's instructions, and an initial list of genes was selected based on observed differences associated with cell types and 5adC treatments (data not shown). The quality of the Methyl Profiler DNA Methylation PCR Array data was verified using sodium bisulfite pyrosequencing assays using primers recommended for this purpose by Qiagen. In our hands, the Methyl-Profiler DNA Methylation PCR Array System could not accurately reveal differences between cell types and 5adCinduced hypomethylation and data were excluded from the study. Therefore the current investigation was completed using sodium bisulfite pyrosequencing analyses of genes that generally fulfilled the above criteria for one or the other cell line (CCND2, DAB2IP, DLEC1, GSTp1, OPCML, RASSF1, RUNX3, SFRP2, and SOCS1).

\subsection{Sodium bisulfite pyrosequencing}

Bisulfite pyrosequencing provides precise quantification of the methylation level of individual CpG sites across a DNA segment with high sensitivity and reproducibility even if the DNA segment includes heterogeneous methylation profile across CpG sites [43-45].

The preparation of the DNA and RNA samples (gene expression analyses are described in the next section) involved growing 1.5 million cells seeded in $100 \mathrm{~mm}$ dishes and incubated in $10 \mathrm{~mL}$ of culture medium. After 24 hours the medium was replaced with experimental medium containing the test chemicals. The culture medium was removed $72 \mathrm{~h}$ later by aspiration. The cells were rinsed once with D-PBS and covered with $1 \mathrm{ml}$ of trypsin solution (0.025\%). After 2-5 min the cells were collected, washed two times in D-PBS, and stored as cell pellets in $1.5 \mathrm{~mL}$ tubes at $-80^{\circ} \mathrm{C}$. Genomic DNA and total RNA were purified from the cell pellets using the AllPrep DNA/RNA Mini Kit, as recommended (Qiagen, Toronto, ON, Canada). Concentration, purity, and integrity of RNA and DNA samples were determined using a NanoDrop Spectrophotometer (NanoDrop Technologies, Wilmington, DE, USA) and Agilent 2100 Bioanalyzer (Agilent Technologies Canada Inc. Mississauga, ON, Canada).

The methodology for pyrosequencing was previously described (Desaulniers et al. 2016, in press), and used a PyroMark Q96 MD instrument (Qiagen). The pyrosequencing assay characteristics and target 
nucleotide sequences for the nine cancer-related genes are described in the supplementary (S) table S1, but the sequences for the primer sets are proprietary to Qiagen. The reliability of the current pyrosequencing data was confirmed by the similarity of the HepG2 cell and primary hepatocyte DNA methylation data (as indicated in table S1B) with the data described by the ENCODE Project [46] accessible through the UCSC Genome Browser (http://www.genome.ucsc.edu/).

To investigate DNA repeated elements, previously published bisulfite pyrosequencing assays were used [3]. DNA methylation was measured in retrotransposons (LINE-1 and AluYb8), and in DNA repeats including Satellite-alpha (Sat- $\alpha$, centromeric), NBL-2 (juxtacentromeric), and D4Z4 (subtelomeric). The assay characteristics, nucleotide sequences for primers, and regions of interest are described in table S2. The data from the D4Z4 assay have to be interpreted with caution considering that the forward and reverse primer set was not specific and generated two bands (supplementary figure S1). This assay was not rejected because the pyrosequencing primer provides additional specificity to the assay, and the pyrograms were highly consistent for the first nine CpG sites.

\subsection{Gene expression analyses}

\subsection{1. mRNA abundance of cancer-related genes and phase-I enzymes}

The expression of liver cancer genes (CCND2, DAB2IP, DLEC1, GSTP1, OPCML, RASSF1, RUNX3, SFRP2, and SOCS1) was measured using custom made $\mathrm{RT}^{2}$ Profiler PCR Array kit (Qiagen), while the mRNA abundance of phase-I enzymes was compared between cell lines using the 96 well plate $\mathrm{RT}^{2}$ Profiler Drug Metabolism Phase-I Enzymes PCR Array kit (Table S3). These kits included reverse transcription reagents, proprietary primer sets, five housekeeping or reference genes, and controls for genomic DNA contamination and reverse transcription performance. For each sample, $2.5 \mu \mathrm{g}$ of total RNA was required. Real-time PCR reactions were run with $\mathrm{RT}^{2}$ SYBR Green Mastermix (Qiagen) on a Bio-Rad CFX96 PCR machine. The PCR temperature program included $10 \mathrm{~min}$ at $95^{\circ} \mathrm{C}$ to activate the HotStart DNA Taq Polymerase followed by 40 cycles of $95{ }^{\circ} \mathrm{C}$ for $15 \mathrm{~s}$ and then $60{ }^{\circ} \mathrm{C}$ for $1 \mathrm{~min}$.

\subsubsection{GSTp1 mRNA following PCB126 treatment}

The quantitative analyses of GSTp1 mRNA were performed following the Qiagen assay's protocol, including primers for GSTp1 (QT00086401), and two reference genes GAPDH (QT00079247) and ACTB (QT00079247). The RT First Strand Kit (Qiagen) was used for cDNA synthesis. $2.0 \mu \mathrm{g}$ of RNA was incubated at $42{ }^{\circ} \mathrm{C}$ for 5 min with genomic DNA elimination mix. After $1 \mathrm{~min}$ on ice, $10 \mu \mathrm{l}$ reverse-transcription mix was added to the previous mixture and incubated at $42{ }^{\circ} \mathrm{C}$ for $15 \mathrm{~min}$. The reaction was stopped by heating at $95^{\circ} \mathrm{C}$ for $5 \mathrm{~min}$, and cDNA was diluted to $50 \mu \mathrm{l}$ with RNase-free water and stored at $-80{ }^{\circ} \mathrm{C}$ for further use. Quantitative SYBR Green RT-PCR (qRT-PCR) was performed using a $25-\mu$ l reaction volume containing $12.5 \mu \mathrm{l}$ SYBR Green Mastermix, $4 \mu \mathrm{l}$ cDNA synthesis reaction, $1 \mu \mathrm{l}$ RT qPCR Primer Assay (10 $\mu \mathrm{M}$ stock), $7.5 \mu \mathrm{l}$ RNase-free water. Reactions were conducted on a CFX96 Real-Time PCR System (Bio-Rad) with a program including activation at $95{ }^{\circ} \mathrm{C}$ for 10 minutes, followed by 40 cycles of $95^{\circ} \mathrm{C}$ for 15 seconds and then $60^{\circ} \mathrm{C}$ for $1 \mathrm{~min}$. All reactions were performed in triplicate, and a negative control lacking cDNA was included. Fold changes compared with no treatment control samples were calculated using the $2^{-\Delta \Delta \mathrm{Ct}}$ methods.

\subsection{Statistical analyses}

The software SigmaPlot version 11.2.0.5 (Systat Software Inc, San Jose, CA, USA) and JMP, version 5.0 [47] were used for the statistical analyses. Prior to conducting the analyses of variance (ANOVA), the original, and when necessary, the log-transformed data were tested for equality of variance (Brown-Forsythe test) and normality (Shapiro-Wilkinson test). When these tests failed the rank-transformed data was analysed using nonparametric tests [48]. Then, multiple comparisons procedures were used to identify significantly different groups (Dunnett test on rank, otherwise Holm-Sidak). DNA methylation of multiple CpG sites was measured within each sample. Therefore, significant effects of treatments, CpG sites, and interactions were detected based on repeated measure analyses, using the sample nested within treatment as the error term under the restricted maximum likelihood (REML) procedure. Then, differences among treatments, or CpG sites, were identified using Tukey HSD tests [47]. In all cases $\mathrm{p}<0.05$ was considered statistically significant. 


\section{RESULTS}

\subsection{DNA methylation differences across cell types}

Figure 1 demonstrates clear differences in methylation pattern of cancer-related genes (CCND2, DAB2IP, DLEC1, GSTp1, OPCML, RASSF1, RUNX3, SFRP2, and SOCS1) based on sodium bisulfite pyrosequencing analyses of DNA from normal liver biopsy samples, non-cancer HC-04 cells and HepG2 cancer cells. The five normal livers had the lowest DNA methylation levels in 6/9 genes (CCND2, DLEC1, OPCML, RASSF1, RUNX3, and SFRP2). The DAB2IP gene was highly methylated in biopsy and HepG2 DNA samples but had reduced methylation in $\mathrm{HC}-04$ cells. In the GSTp1 gene, the highest and lowest levels of methylation were in the HepG2 and HC-04 cells, respectively, whereas the SOCS1 gene was equally highly methylated in all cell types. The HC-04 and HepG2 cell lines showed statistically different levels of methylation in five genes (CCND2, DAB2IP, DLEC1, GSTp1, and RUNX3), with only one gene (CCND2) having higher methylation levels in the HC-04 than HepG2 cells. Methylation of DNA repeated elements also revealed major differences across the three cell types (Figure 2). However, in contrast to cancer-related genes, and as expected, DNA repeated elements generally exhibited higher methylation levels in the biopsy samples than in the cell lines (4/5 repeated elements, AluYb8, LINE-1, Sat- $\alpha$, and NBL-2), but with the lowest methylation level found in the HC-04 cells. No overall differences in D4Z4 methylation were found between the different cell types. Levels of methylation in Sat- $\alpha$, and NBL-2, were not statistically different between the two cell lines. Overall, the investigation of five human liver biopsy samples was sufficient to clearly demonstrate DNA methylation differences between normal human liver samples and both cell lines.

\subsection{Effects of hypomethylating drugs (5adC, SGI-1027)}

All repeated elements and the nine genes were sensitive to 5adC-induced hypomethylation (Figure 3). Moreover, in all targets, 5adC induced a "U” shape dose-response effect with a DNA methylation nadir observed at $5 \mu \mathrm{M}$, and generally a return to near normal DNA methylation levels at $50 \mu \mathrm{M}$ (Figure 3). These changes in DNA methylation are occurring in the absence of overt toxicity. In both cell lines, the first statistically significant decrease in the index of cellular abundance occurs at $25 \mu \mathrm{M}$ but it remains above $80 \%$ even at $50 \mu \mathrm{M}$ (Figure $4 \mathrm{~A}$ and $4 \mathrm{~B}$ ). The magnitudes of the 5adC-induced reduction in DNA methylation vary between cell types and across DNA targets. Using the gene DAB2IP as an example, table 1 indicates that the pyrosequencing assay interrogated $6 \mathrm{CpG}$ sites. The difference in methylation between the control and 5adC (5 $\mu \mathrm{M}$ as the most potent concentration)-treated HC-04 cells was 9.9\% (averaged for all CpG positions). In contrast, this reduction in DNA methylation observed in HepG2 cells (26.5\%) was larger than in the HC-04 cell line ( $p=0.005$; the $p$ value was provided beside the cell line with the largest reduction). Table 1 also suggests that generally larger reduction in DNA methylation occurred more frequently in HepG2 than in HC-04 cells. Indeed, larger reductions were observed in HepG2 cells 4/5 times for the DNA repeated elements and 5/9 times for the cancer-related genes. The 5adC-induced reduction in DNA methylation of the cancer-related genes was not always associated with changes in mRNA expression, or related to the magnitude of the reduction in DNA methylation (Figure 5 and Table 1). For example, the 5adC reduction in methylation of DAB2IP was larger in HepG2 cells but affected mRNA expression only in HC-04 cells. In table 1, the genes that showed 5adC-induced changes in mRNA expression are identified by the superscript " $m$ " beside the name of the cell line. 5adC (5 $\mu \mathrm{M})$ significantly altered mRNA expression in six genes in HC-04 cells (DAB2IP, DLEC1, GSTp1, RASSF1, RUNX3, and SOCS1), but in only three genes in HepG2 cells (GSTp1, RASSF1, and RUNX3).

Based on our results with HC-04 or HepG2 cells, DAB2IP, DLEC1, GSTp1, RASSF1, RUNX3, and SOCS1 genes, fulfill our previously described selection criteria: (1) these genes are relevant to liver cancer, (2) they differed in DNA methylation across the cell types, and (3) they showed 5adClabile DNA methylation pattern associated with changes in gene expression in at least one cell line, suggesting that the DNA methylation change is biologically relevant. Therefore, we hypothesised that these hepatic genes would be good candidates to investigate epigenetic events following exposure to EC. 

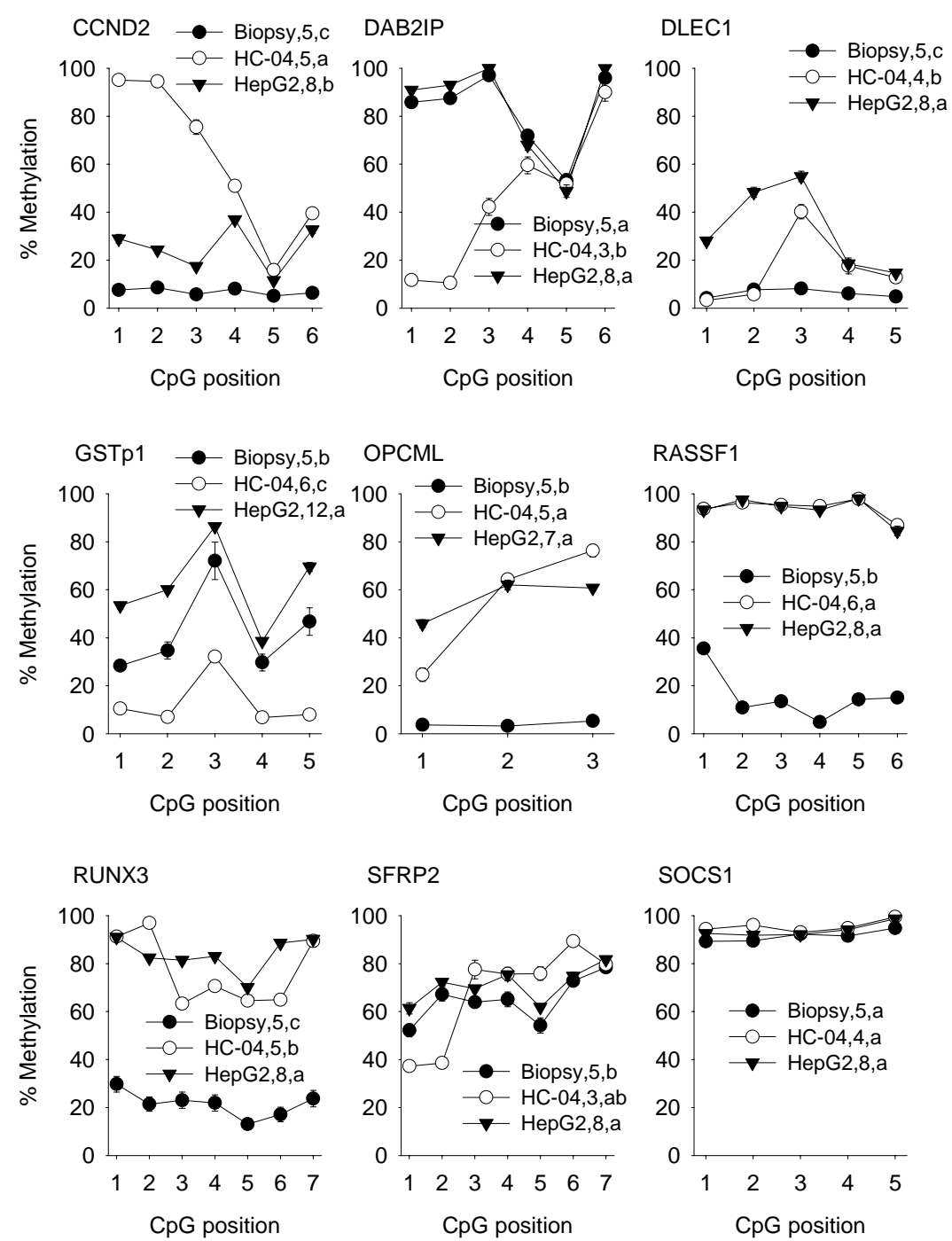

Figure 1. DNA methylation pattern of nine cancer-related genes between normal liver biopsy samples, the non-cancer HC-04 cells and the HepG2 cancer cells. The results are expressed as percentages of cytosines that are methylated at specific CpG dinucleotides across DNA segments that include, depending on the gene, from 3 to 7 different CpG sites. The legend provides the numbers of samples analysed and letters identifying the DNA sources with significantly different methylation pattern. The letter "a" was assigned to the largest value over all CpG sites. Groups that do not share the same letters are significantly different $(\mathrm{p}<0.05)$. Mean \pm s.e. Error bars are not visible when masked by the symbols.

In our hands, SGI-1027 was ineffective as positive control to induce DNA hypomethylation. After treating HepG2 cells at non-toxic to toxic concentrations $(0.1,0.5,1.0$, and $2.5 \mu \mathrm{M})$ and over numerous exposure scenarios $(24 \mathrm{~h}, 72 \mathrm{~h}, 96 \mathrm{~h}, 7$ to 14 days), SGI-1027 had no effect on the methylation of LINE-1 and AluYb8, and no effect on global methylation as measured by the previously described [49] pyrosequencing luminometric assay (data not shown). SGI-1027 was reported to induce
DNA hypomethylation by some [38], and not by others [50].

\subsection{Effects of PCB on phase-1 enzyme expressions and on cellular abundance}

The expressions of 84 phase-I enzyme mRNAs were measured at a concentration of $10 \mu \mathrm{g} / \mathrm{mL}(30.6 \mu \mathrm{M}$ for PCB126) using the 96-well plate $\mathrm{RT}^{2}$ Profiler Drug Metabolism Phase-I Enzymes PCR Array kit. For comparison PCB153, a congener that does not 

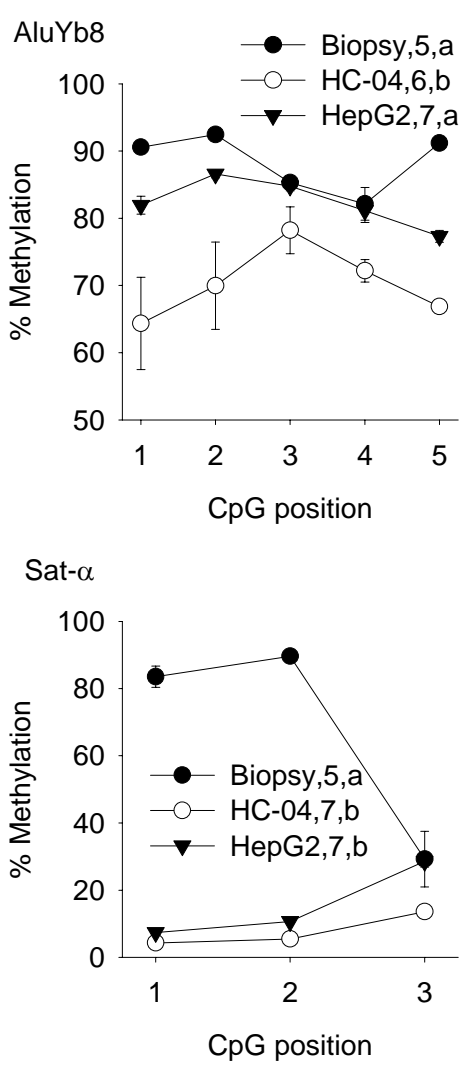
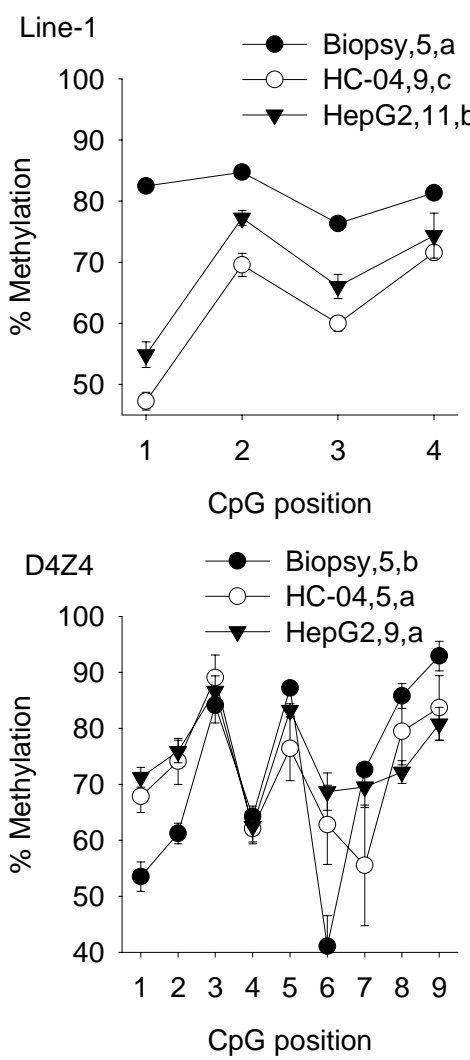

NBL-2

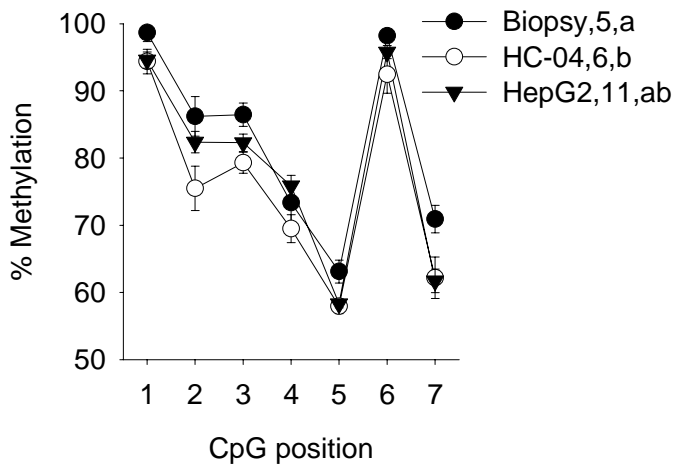

Figure 2. DNA methylation (\% methylated cytosine) pattern of repeated sequences between normal liver biopsy samples, the non-cancer HC-04 cells, and the HepG2 cancer cells. The results are expressed as percentages of cytosines that are methylated at specific CpG dinucleotides across DNA segments that include, depending on the gene, from 3 to 9 different CpG sites (see Figure 1 label for additional description).

bind to the AhR [51], was also tested at $10 \mu \mathrm{g} / \mathrm{mL}$ $(27.7 \mu \mathrm{M})$. As expected, CYP1A1 showed more than 3000 and 4000 times more mRNA in the PCB126treated groups than in control HepG2 and HC-04 cells, respectively (Table 2). The expression of 2, 10 , and 2 genes were altered by the NoTx (no treatment), PCB126, and PCB153 treatment relative to the DMSO control group in the HepG2 cells, respectively. In contrast, only the PCB126 treatment affected gene expressions in the HC-04 cells, with 3 and 12 genes with reduced or increased expression, respectively. In addition to demonstrating biological potency of the PCB126 concentration, the phase- 1 gene constitutive mRNA expressions further characterize cell line differences; 11 mRNAs were constitutively more abundant in the HepG2 than 


\section{A. Effects of 5adC on DNA methylation of genes in HC-04 cells}
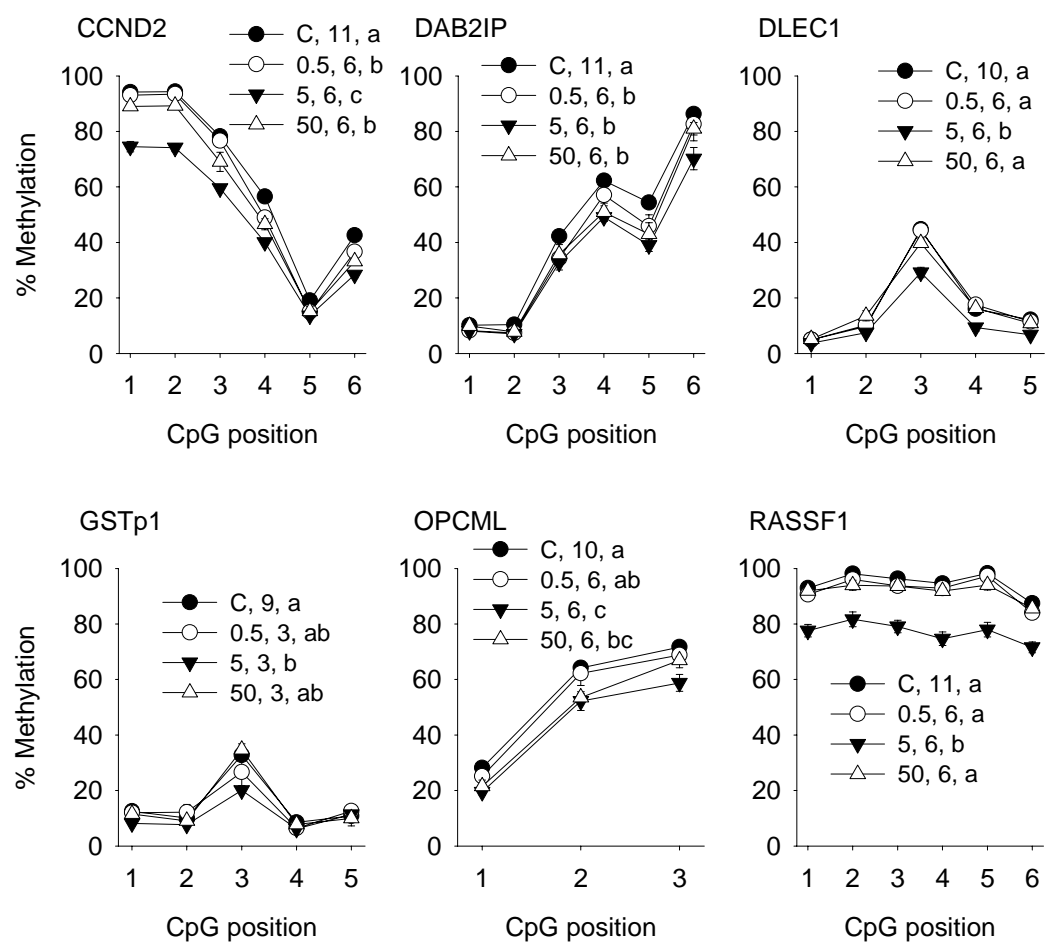

RASSF1
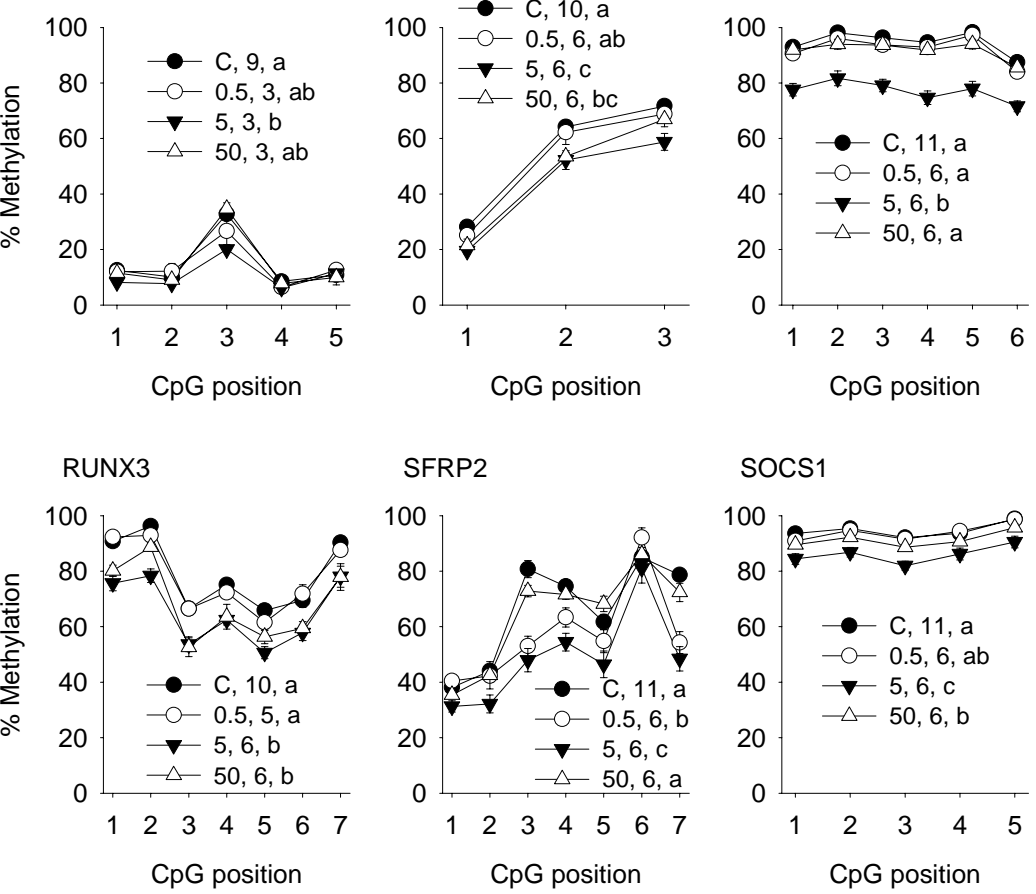

socs1

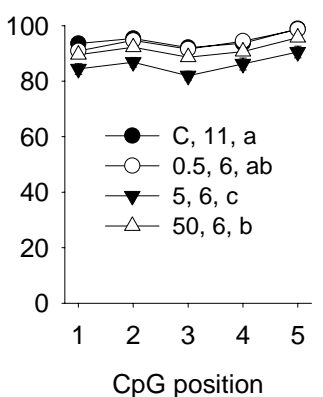

B. Effects of 5adC on DNA methylation of repeated elements in HC-04 cells
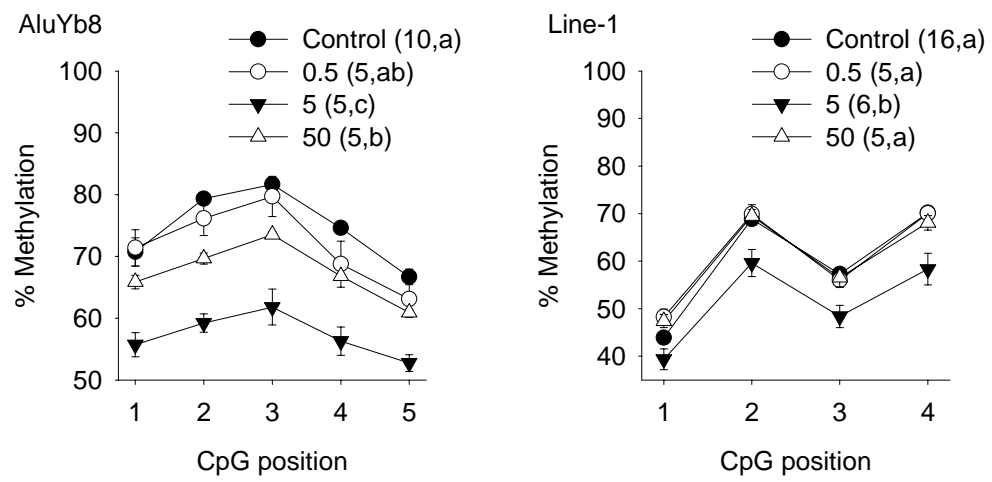

Figure 3 
Figure 3 continued..
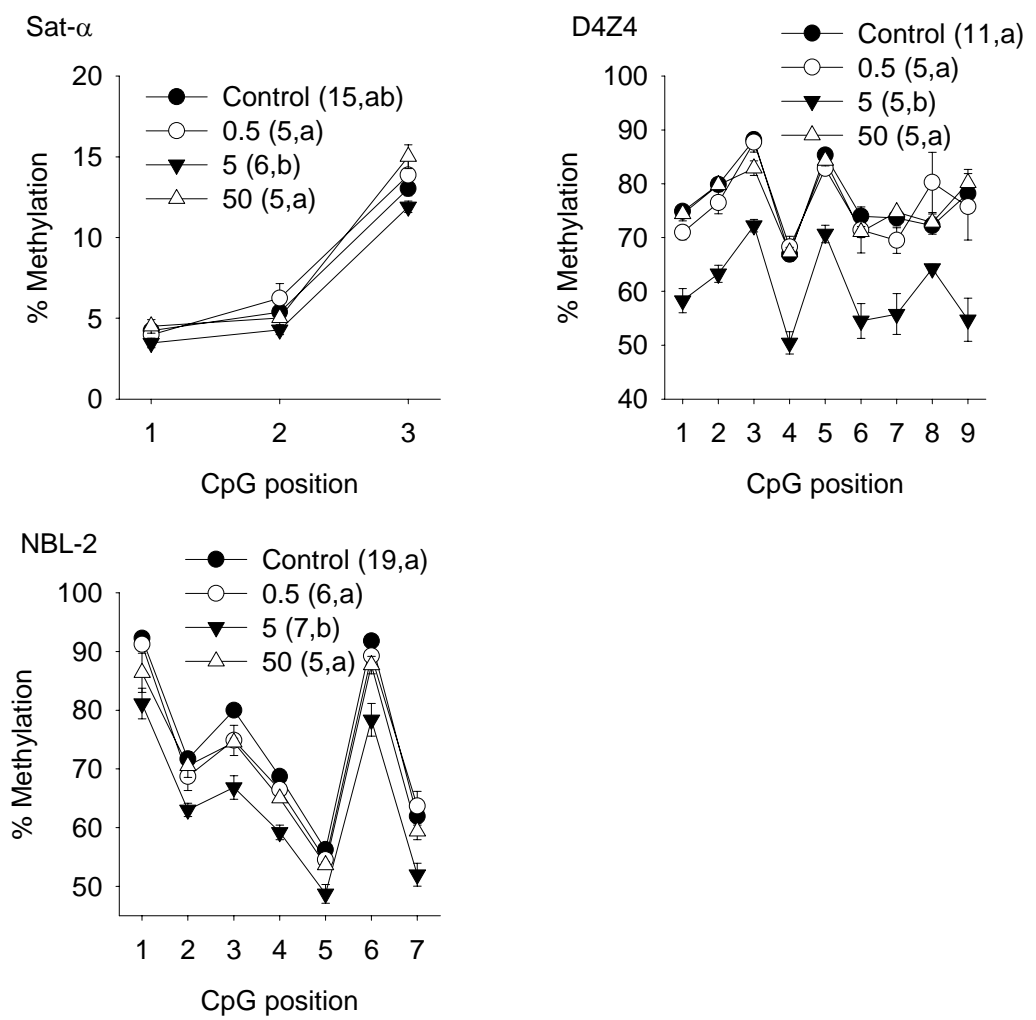

\section{Effects of 5adC on DNA methylation of genes in HepG2 cells}
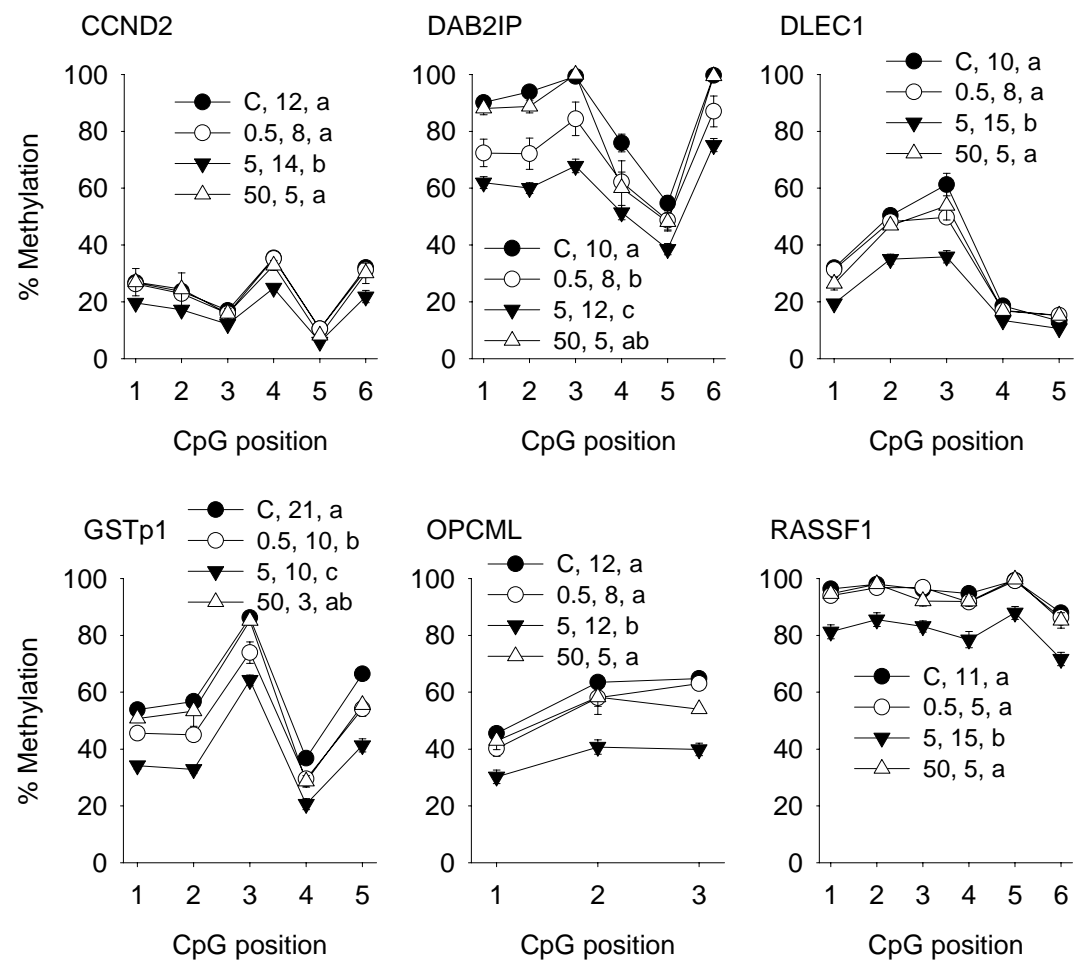

RASSF1

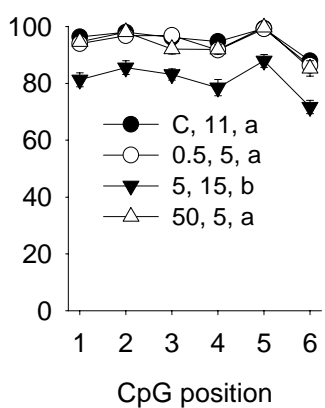



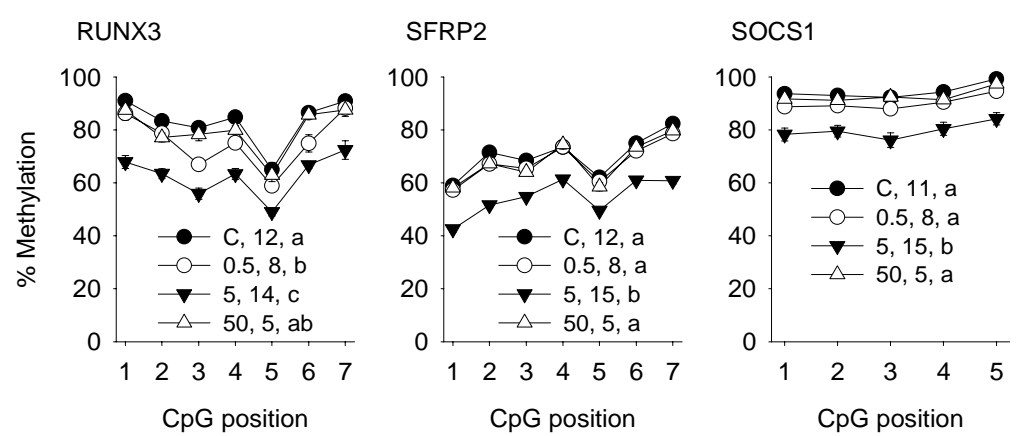

D. Effects of 5adC on DNA methylation of repeated elements in HepG2 cells
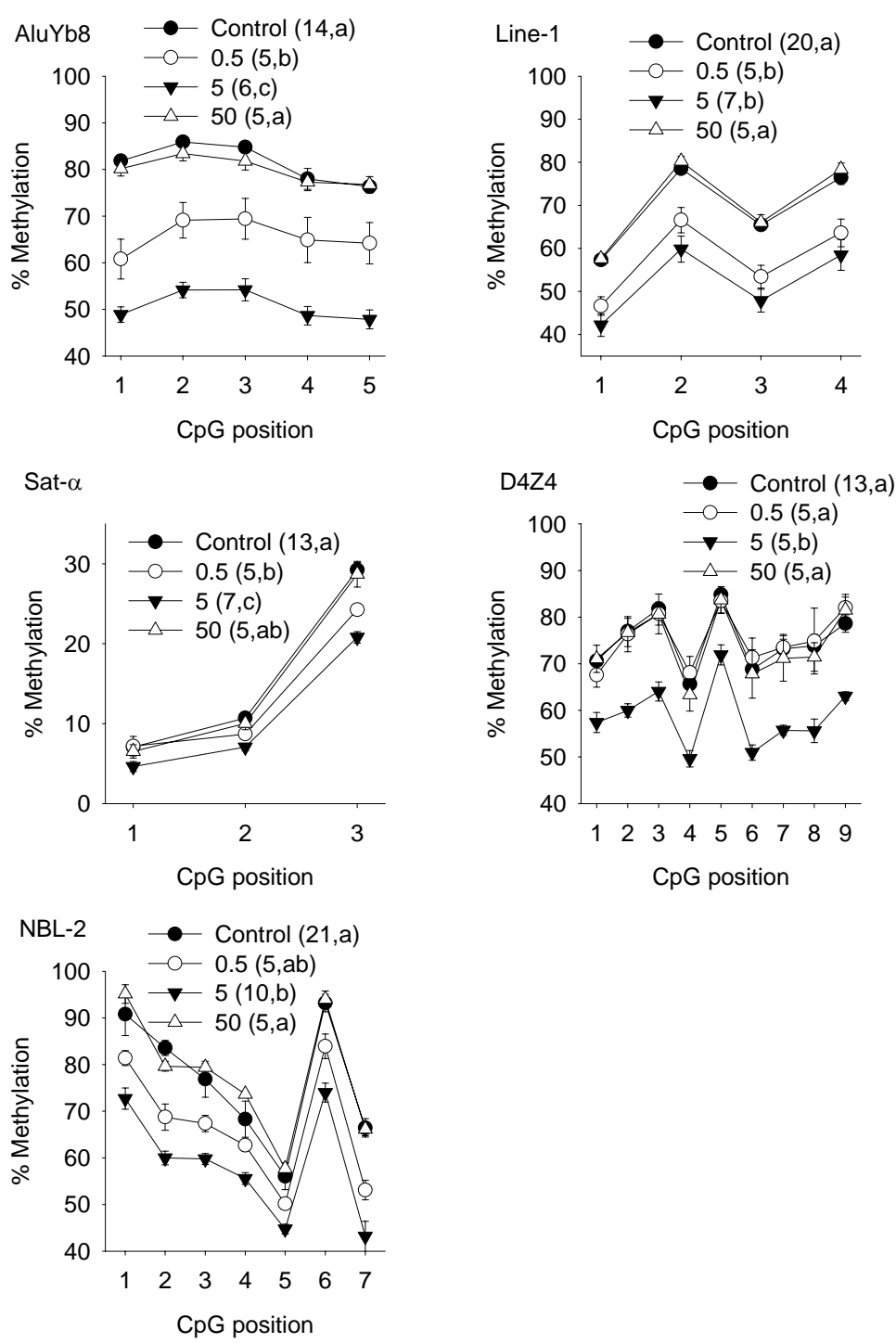

Figure 3. Differences in DNA methylation (\% methylated cytosine) of nine cancer-related genes and DNA repeats following 72-h exposure to increasing concentrations of 5adC in non-cancer HC-04 cells (Figure 3A, 3B), and HepG2 cancer cells (Figure 3C, 3D). The legend provides the concentrations of 5adC [either Control (C), 0.5 , 5 , or $50 \mu \mathrm{M}$ ], the number of experiments with one dish per treatment per experiment, and letters to indicate the significantly different groups $(\mathrm{p}<0.05)$, as in Figure 1. Mean \pm s.e. 
A) $\mathrm{HC}-04,5 \mathrm{adC}$

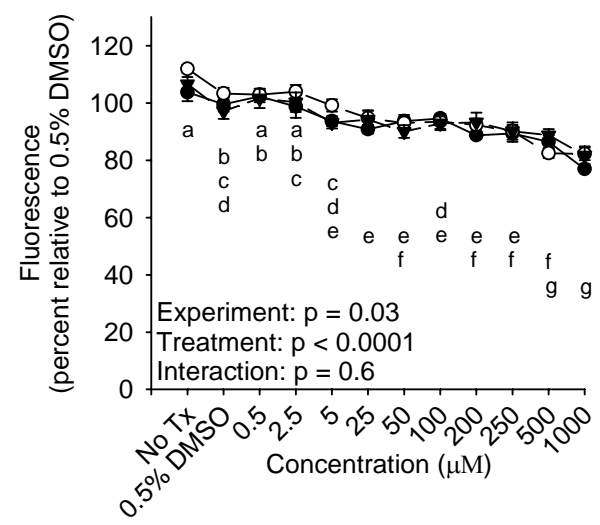

C) HC-04, PCB126 Experiment: $p<0.0001$

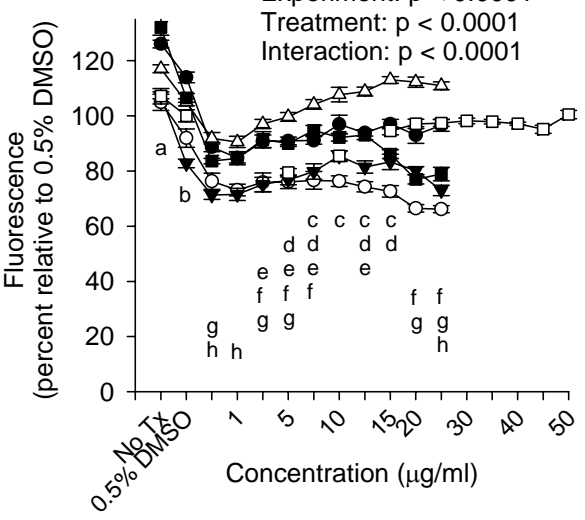

B) HepG2, 5adC

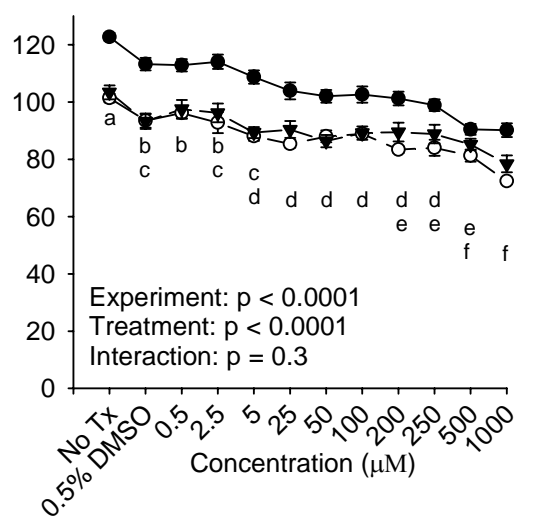

D) HepG2, PCB126

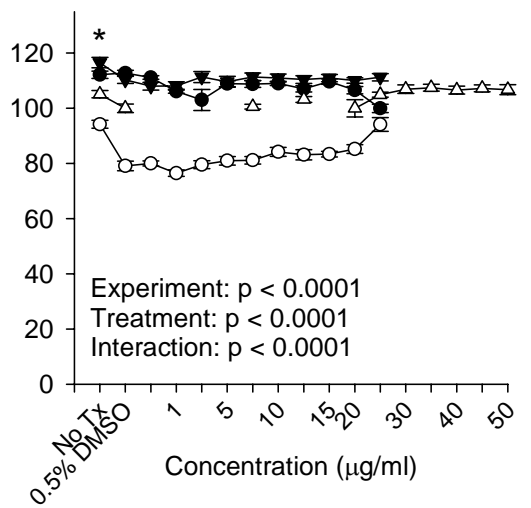

Figure 4. Effects of 72-h exposure to increasing concentrations of 5-aza-2'-deoxycytidine (5adC) (Figure 4A and B) and PCB126 (Figure 4C and D) on the alamarBlue ${ }^{\circledR}$ assay providing an index of cellular abundance. 5adC was tested in three experiments ( 8 wells per group, mean \pm s.e) for each cell lines, while PCB126 was tested in 6 and 4 experiments in HC-04 and HepG2 cells, respectively (6 wells per group, mean \pm s.e). In Figure 4C and 4D, one experiment included concentrations up to $50 \mu \mathrm{g} / \mathrm{ml}$ and was not included in the statistical analyses. The data was expressed as percentages relative to the average of all DMSO control samples from all experiments and then analysed by two way analysis of variance (ANOVA). Multiple comparison procedures over all experiments revealed significant differences across concentrations (Tukey HSD p $<0.05$ ) that are identified with letters with "a" assigned to the largest group value. Concentration groups that do not share the same letters are significantly different. No Tx: no treatment. *: in Figure 4C, only the NoTx group is different from the DMSO group (Tukey HSD p < 0.05). Different symbols represent separate experiments.

in the HC-04 cells, while three mRNAs were statistically more abundant in the HC-04 than in the HepG2 cells (Table 3).

The index of cellular abundance (alamarBlue ${ }^{\circledR}$ assay) measured from the 72-h concentration-responses for PCB126 (Figure 4C) in HC-04 cells, revealed significant decreases over all experiments from the no treatment group to the DMSO control (DMSO showed significant effects in all graphs from figure 4), and then to the first concentration of PCB126 $(0.5 \mu \mathrm{g} / \mathrm{ml})$. However, cellular abundance then increased in the 7.5 to $15 \mu \mathrm{g} / \mathrm{ml}$ treatment groups with no significant decline relative to the $0.5 \mu \mathrm{g} / \mathrm{ml}$. In HepG2 cells (Figure 4D), all concentration groups were similar to the DMSO control group. Note that in one experiment performed with each cell line, the concentrations of PCB126 were increased up to $50 \mu \mathrm{g} / \mathrm{ml}$, which overall suggests no overt sign of toxicity in either cell line. The PCB126 concentrations far exceed those encountered in human blood and it would have been irrelevant to increase them further. In the general population, 
Table 1. DNA methylation reduction (mean, median, min., max. \% methylated cytosine) averaged over all CpG sites in 5adC (5 $\mu \mathrm{M})$-treated HC-04 and HepG2 cells ${ }^{1}$.

\begin{tabular}{|c|c|c|c|c|c|c|c|}
\hline Gene & p value ${ }^{2}$ & Cell line & $\begin{array}{c}\text { Number of } \\
\text { CpGs }\end{array}$ & Mean & Median & Min. & Max. \\
\hline \multicolumn{8}{|c|}{ DNA repeated elements } \\
\hline \multirow[t]{2}{*}{ AluYb8 } & & HC-04 & 5 & 17.4 & 18.3 & 13.9 & 20.1 \\
\hline & $\mathrm{p}<0.0001$ & HepG2 & 5 & 30.6 & 30.6 & 28.4 & 32.9 \\
\hline \multirow[t]{2}{*}{ D4Z4 } & & HC-04 & 9 & 16.5 & 16.6 & 8.0 & 23.4 \\
\hline & & HepG2 & 9 & 16.2 & 17.0 & 12.9 & 18.2 \\
\hline \multirow[t]{2}{*}{ L1 } & & HC-04 & 4 & 8.6 & 9.1 & 4.5 & 11.8 \\
\hline & $p=0.03$ & HepG2 & 4 & 17.3 & 17.8 & 15.1 & 18.7 \\
\hline \multirow[t]{2}{*}{ NBL-2 } & & HC-04 & 7 & 10.5 & 9.9 & 7.5 & 13.4 \\
\hline & $p=0.01$ & HepG2 & 7 & 17.9 & 18.1 & 11.3 & 23.6 \\
\hline \multirow[t]{2}{*}{ SAT-a } & & HC-04 & 3 & 1.0 & 1.1 & 0.8 & 1.1 \\
\hline & $p=0.05$ & HepG2 & 3 & 4.8 & 3.6 & 2.4 & 8.4 \\
\hline \multicolumn{8}{|c|}{ Cancer-related genes } \\
\hline \multirow[t]{2}{*}{ CCND2 } & $p=0.03$ & HC-04 & 6 & 15.7 & 17.5 & 5.4 & 20.2 \\
\hline & & HepG2 & 6 & 7.3 & 6.8 & 4.7 & 10.6 \\
\hline \multirow[t]{2}{*}{ DAB2IP } & & $\mathrm{HC}-04^{\mathrm{m}}$ & 6 & 9.9 & 11.3 & 2.1 & 16.1 \\
\hline & $\mathrm{p}=0.005$ & HepG2 & 6 & 26.5 & 26.4 & 16.2 & 33.8 \\
\hline \multirow[t]{2}{*}{ DLEC1 } & & $\mathrm{HC}-04^{\mathrm{m}}$ & 5 & 6.2 & 5.4 & 1.2 & 15.5 \\
\hline & & HepG2 & 5 & 12.2 & 12.6 & 2.6 & 25.4 \\
\hline \multirow[t]{2}{*}{ GSTp1 } & & $\mathrm{HC}-04^{\mathrm{m}}$ & 5 & 4.2 & 2.5 & -0.6 & 12.7 \\
\hline & $\mathrm{p}=0.01$ & HepG $2^{\mathrm{m}}$ & 5 & 21.4 & 22.0 & 16.2 & 25.1 \\
\hline \multirow[t]{2}{*}{ RASSF1 } & $p=0.03$ & HC- $04^{\mathrm{m}}$ & 6 & 17.5 & 16.8 & 15.4 & 20.3 \\
\hline & & HepG $2^{\mathrm{m}}$ & 6 & 14.1 & 14.1 & 11.4 & 16.2 \\
\hline \multirow[t]{2}{*}{ RUNX3 } & & $\mathrm{HC}-04^{\mathrm{m}}$ & 7 & 13.9 & 12.8 & 11.7 & 17.9 \\
\hline & $\mathrm{p}=0.003$ & HepG $2^{\mathrm{m}}$ & 7 & 20.5 & 20.0 & 15.9 & 24.9 \\
\hline \multirow[t]{2}{*}{ SOCS1 } & & $\mathrm{HC}-04^{\mathrm{m}}$ & 5 & 8.7 & 8.5 & 7.5 & 10.1 \\
\hline & $\mathrm{p}=0.01$ & HepG2 & 5 & 14.8 & 15.1 & 13.5 & 16.2 \\
\hline \multirow[t]{2}{*}{ OPCML } & & HC-04 & 3 & 11.2 & 12.0 & 8.7 & 12.9 \\
\hline & $p=0.05$ & HepG2 & 3 & 21.0 & 22.8 & 15.3 & 24.9 \\
\hline \multirow[t]{2}{*}{ SFRP2 } & & HC-04 & 7 & 17.3 & 15.2 & 3.9 & 32.8 \\
\hline & & HepG2 & 7 & 15.8 & 14.0 & 12.2 & 21.6 \\
\hline
\end{tabular}

1: The percent methylation from the $5 \mathrm{adC}(5 \mu \mathrm{M})$-treated group was subtracted from that in the control group (original data from Figure 3). This DNA methylation reduction was averaged over the CpG positions from which the mean, median, min. and max. values are shown here.

2: p value of a non-parametric Wilcoxon rank-sums test comparing cell lines. The p value is located beside the cell line with the largest reduction.

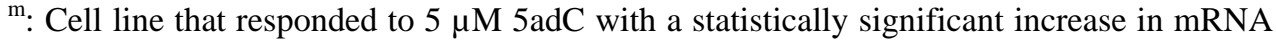
expression (Figure 4).

minimal and maximal concentrations of AhRagonists in human blood based on 2,3,7,8-tetrachlorodibenzodioxin (TCDD) toxic equivalent (TEQ) were reported as 7.1 and $81.2 \mathrm{pg} / \mathrm{g}$ of lipids, respectively [32]; however up to $56,000 \mathrm{pg} / \mathrm{g}$ was measured in the accidentally exposed population in Seveso [52]. Based on $636 \mathrm{mg}$ lipids/dl [53] and assuming that one $\mathrm{ml}$ of blood equal $1 \mathrm{~g}$, these values can be estimated at $0.045 \mathrm{pg} / \mathrm{ml}$ and $0.516 \mathrm{pg} / \mathrm{ml}$ of whole blood. The concentrations of PCB126 in the culture 

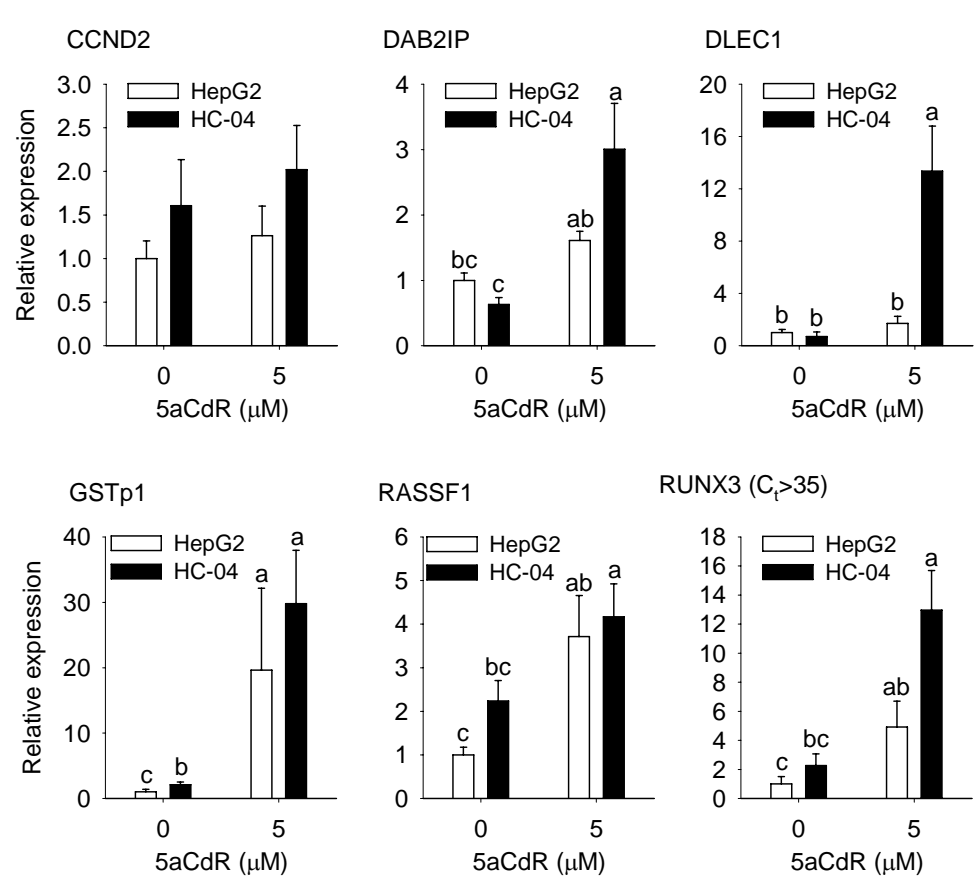

RUNX3 $\left(C_{\mathrm{t}}>35\right)$
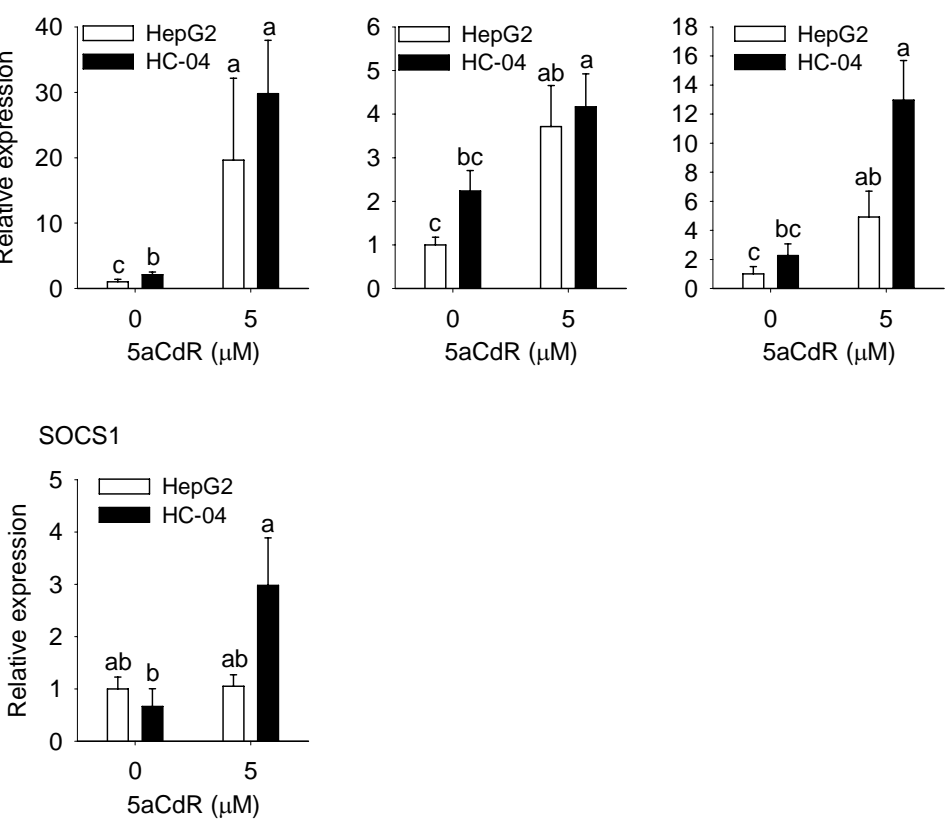

Figure 5. Effects of 72-h exposure to $5 \mu \mathrm{M}$ 5adC on mRNA expression of cancer-related genes in non-cancer HC-04 (black bar) and in cancer HepG2 cells (open bar). The data (mean \pm s.e.) is presented relative to the HepG2 control level. The number of cultures per group varies between $n=4$ and $n=7$. The letter "a" was assigned to the largest value. Groups that do not share the same letters are significantly different $(p<0.05)$. Note: The analysis of mRNA expression for OPCML and SFRP2 revealed threshold cycle (Ct) that exceeded 35 in both control and 5adCtreated samples which prevented reliable measurements. The mRNA abundance of RUNX3 was also measured at $\mathrm{Ct}>35$, but an effect of 5adC could still be detected as shown here.

medium varied from 0.5 to $50 \mu \mathrm{g} / \mathrm{ml}$, or 0.05 to $5 \mu \mathrm{g} / \mathrm{ml}$ following multiplication by the TCDDtoxic equivalency factor (TEF) of 0.1 for PCB126 [33]. Thus the culture medium concentrations were roughly one to ten million times larger than in blood.

\subsection{Effects of PCB126 on DNA methylation and mRNA expression in cancer-related genes}

The intent was to select concentrations that would be known to induce biological effects without inducing overt toxicity. Therefore, effects on DNA methylation were examined at the concentration tested for effects on phase- 1 enzyme expressions $(10 \mu \mathrm{g} / \mathrm{ml}$ or $30.6 \mu \mathrm{M})$ and at 5 and $50 \mu \mathrm{g} / \mathrm{ml}$ (15.3 and $153 \mu \mathrm{M}$ ). PCB126 induced a small but statistically significant decrease in DNA methylation overall CpG sites only at $150 \mu \mathrm{M}$ for the GSTp1 gene, and only in HepG2 cells (Figure 6A). However, PCB126 induced significant increases in GSTp1 mRNA expression in both cell lines (Figure 6B and 6C).

PCB126 had no significant effects on methylation of DNA repeats and on the other cancer-related genes. 


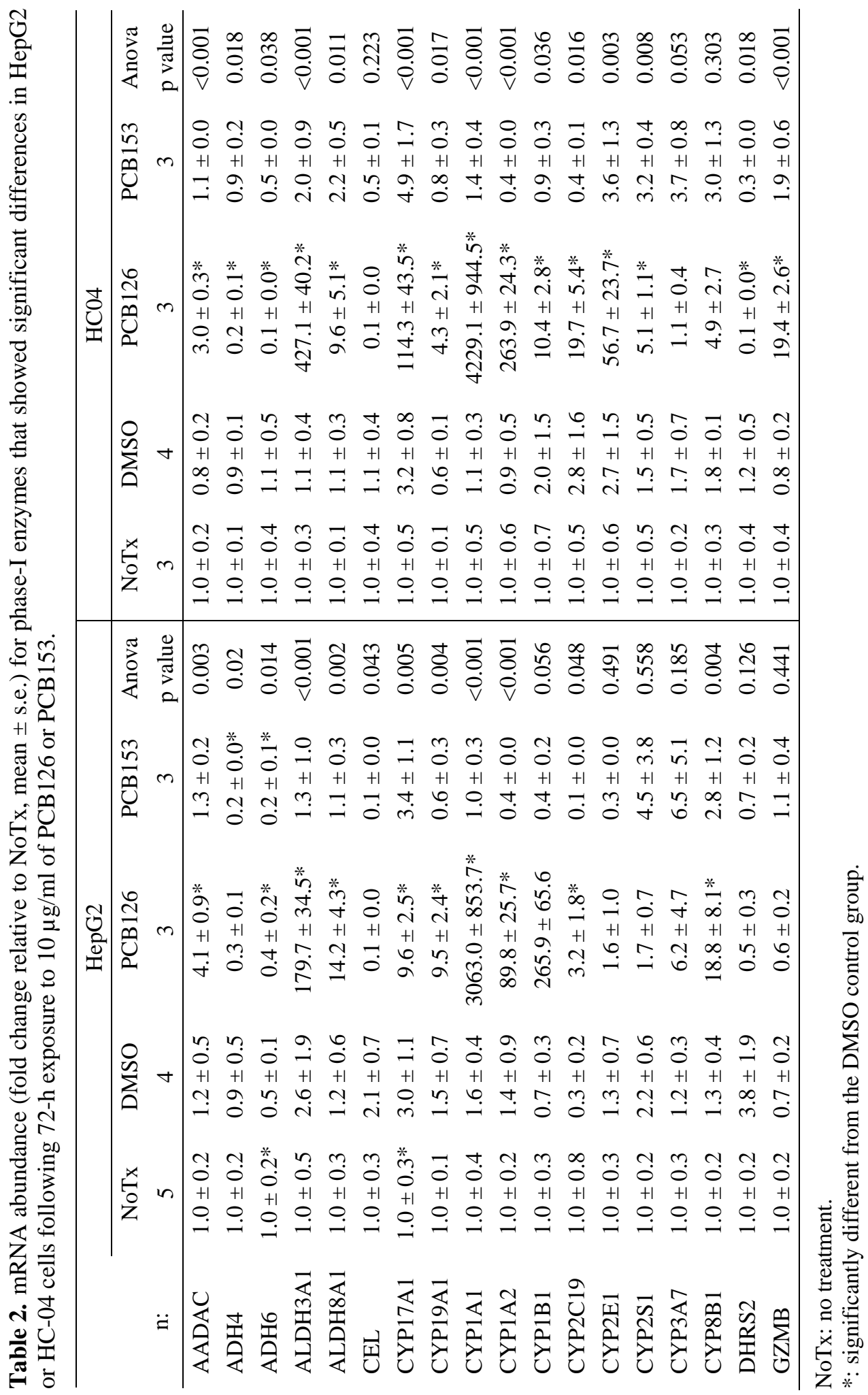


Table 3. List of phase-I enzymes with constitutive mRNA expression $(\Delta \mathrm{Ct})$ significantly different between the HepG2 cells and the HC-04 cells. The list of genes was sorted based on the ratio HepG2/HC-04 ${ }^{\mathrm{a}}$.

\begin{tabular}{|c|c|c|c|c|c|c|}
\hline & \multicolumn{2}{|r|}{ HepG2 } & \multicolumn{2}{|r|}{ HC-04 } & \multirow{2}{*}{$\frac{\text { HepG2 }}{\text { HC-04 }}$} & \multirow{2}{*}{$\begin{array}{c}\text { T-test } \\
\text { p value }\end{array}$} \\
\hline & $\mathrm{n}$ & Mean \pm s.e & $\mathrm{n}$ & Mean \pm s.e. & & \\
\hline CYP3A7 & 9 & $0.0067 \pm 0.0014$ & 7 & $0.0319 \pm 0.0094$ & 0.21 & 0.0370 \\
\hline CYP2S1 & 9 & $0.0023 \pm 0.0005$ & 7 & $0.0069 \pm 0.0018$ & 0.34 & 0.0413 \\
\hline CYР3А5 & 9 & $0.0634 \pm 0.0248$ & 7 & $0.1661 \pm 0.0291$ & 0.38 & 0.0189 \\
\hline CYP8B1 & 9 & $0.0029 \pm 0.0006$ & 7 & $0.0007 \pm 0.0001$ & 4.06 & 0.0039 \\
\hline CYP17A1 & 9 & $0.0008 \pm 0.0002$ & 7 & $0.0002 \pm 0.0001$ & 4.75 & 0.0336 \\
\hline CYP1B1 & 9 & $0.0008 \pm 0.0002$ & 7 & $0.0002 \pm 0.0001$ & 4.82 & 0.0097 \\
\hline CYP1A1 & 9 & $0.0026 \pm 0.0006$ & 7 & $0.0005 \pm 0.0001$ & 4.85 & 0.0109 \\
\hline FMO5 & 9 & $0.0919 \pm 0.0088$ & 7 & $0.0186 \pm 0.0054$ & 4.94 & $<0.0001$ \\
\hline CYP2E1 & 9 & $0.0014 \pm 0.0004$ & 7 & $0.0002 \pm 0.0001$ & 8.41 & 0.0152 \\
\hline ADH4 & 9 & $0.0901 \pm 0.0191$ & 7 & $0.0101 \pm 0.0008$ & 8.96 & 0.0031 \\
\hline ADH6 & 5 & $0.3217 \pm 0.0502$ & 7 & $0.0302 \pm 0.0090$ & 10.66 & 0.0038 \\
\hline СҮРЗА43 & 9 & $0.0064 \pm 0.0017$ & 7 & $0.0006 \pm 0.0001$ & 11.41 & 0.0096 \\
\hline Cel & 9 & $0.0259 \pm 0.0066$ & 7 & $0.0016 \pm 0.0004$ & 15.87 & 0.0064 \\
\hline DPYD & 9 & $0.0160 \pm 0.0036$ & 7 & $0.0003 \pm 0.0001$ & 59.15 & 0.0023 \\
\hline
\end{tabular}

a: These ratios demonstrate that three genes (CYP3A7, CYP2S1, and CYP3A5) were significantly $(p<0.05)$ less expressed in HepG2 than in HC-04 cells, while the eleven other genes were more expressed in the HepG2 than in the HC-04 cell line $(\mathrm{p}<0.05)$.

Nevertheless, it increased the expression of DAB2IP in HepG2 cells (NoTx, $\mathrm{n}=7,0.6 \pm 0.2$; DMSO, $\mathrm{n}=16,1.0 \pm 0.1 ; 15 \mu \mathrm{M}, \mathrm{n}=3,1.1 \pm 0.4 ; 30 \mu \mathrm{M}$, $\mathrm{n}=4,3.1 \pm 0.3^{*} ; 150 \mu \mathrm{M}, \mathrm{n}=3,1.8 \pm 0.4$ ) without a clear dose-response pattern.

\subsection{Batch effect and seeding density}

The experiments measuring effects of PCB126 on GSTp1 (Figure 6A) and those comparing methylation across cell types (Figure 1) were from different pool of frozen HepG2 cells. This may explain the differences in methylation level of GSTp1 observed in figure 1 and figure 6A. This batch effect is a confounding factor but has no impact given that conclusions were derived within, and not across, experiments. Seeding density can also be a confounding factor for in vitro experiments for some genes (Figure 7). Seeding HepG2 cells at low density (21,000 to 42,000 cells/ $/ \mathrm{cm}^{2}$ ) compared to high density $\left(63,000 \mathrm{cells} / \mathrm{cm}^{2}\right)$ led to a transient 10\% drop in methylation of AluYb8 after 120-144 h of culture (Figure 7). This seeding density effect (monitored here using two genes AluYb8 and GSTp1) was not observed for GSTp1, and did not occur in HC-04 cells. Seeding density was kept constant across experiments.

\section{DISCUSSION}

This manuscript describes basal and 5adC-induced DNA methylation and gene expression differences between normal human liver cells, a classic cancer cell line model (HepG2 cells), and an emerging non-cancer cell line model, the HC-04 cells. These differences provide insights for further studies aiming at understanding cancer epigenetics. In addition the current work highlights that short-term (72 h) exposure to PCB126 (a known rodent hepatocarcinogen) induced GSTp1 gene expression and DNA hypomethylation of the promoter in HepG2 cells without significant changes in methylation of other investigated genes.

\subsection{DNA methylation differences between normal livers and the non-cancer HC-04 cells}

Even though the HC-04 cell line originated from a tissue adjacent to a tumor, DNA methylation patterns of gene promoters and of repeated elements in this cell line were different from those of normal livers. In HC-04 cells, DAB2IP, GSTp1, AluYb8, LINE-1, Sat- $\alpha$ and NBL2 were hypomethylated whereas CCND2, DLEC1, OPCML, RASSF1, RUNX3, and D4Z4 were hypermethylated relative to normal livers. Hypothetically, these differences 

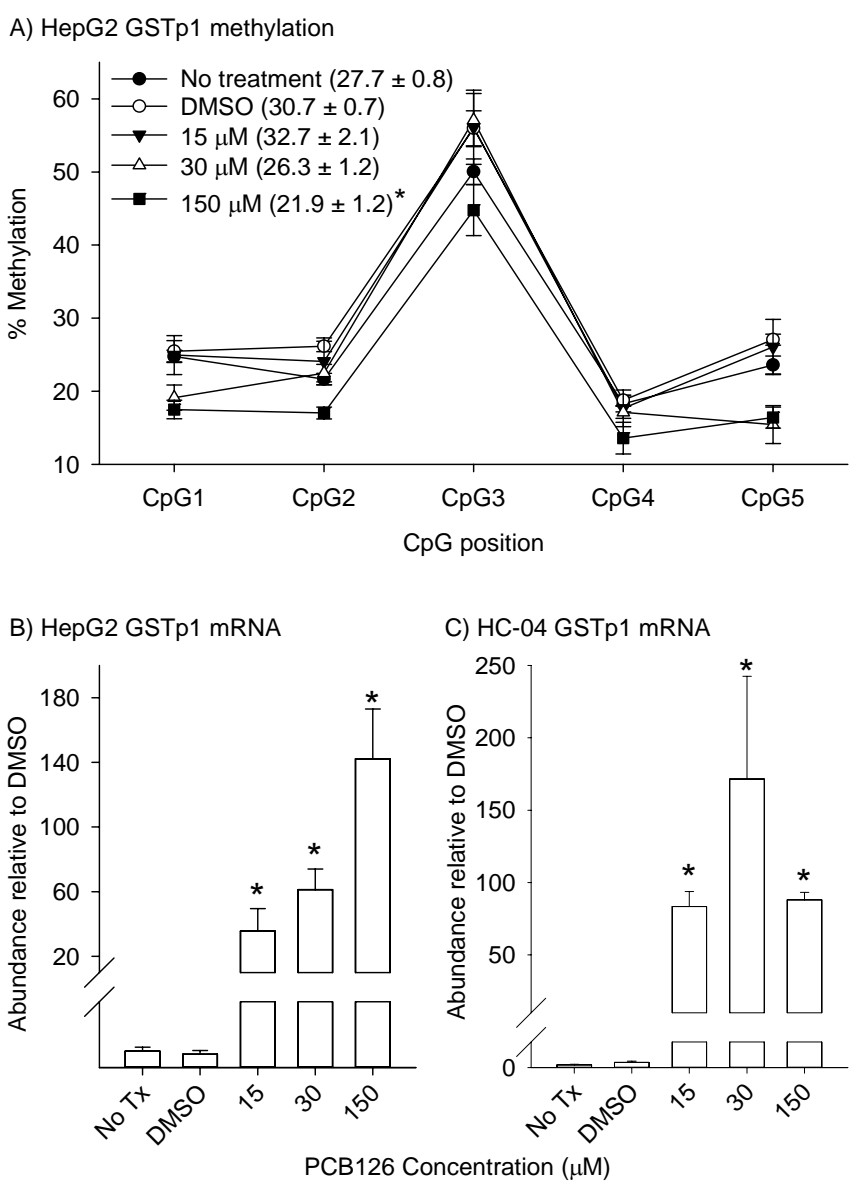

Figure 6. Effects of PCB126 on A) DNA methylation (\% methylated cytosine) of the GSTp1 gene promoter in HepG2 cells, and B) on GSTp1 mRNA expression in the same HepG2 samples, and C) in HC-04 cells. The nested ANOVA revealed an effect of concentration ( $p=0.007$ ) associated with significant differences in the average of CpG1 to CpG5 methylation between the DMSO (30.7 \pm 0.8$)$ and the $150 \mu$ M concentration $(21.9 \pm 1.2)$ (Tukey HSD p $<0.05$ ). The ANOVA for GSTp1 mRNA expression was performed on log transformed data. *: different from the DMSO treated group (Holm-Sidak p < 0.05). The number of samples were 13, 7, 6, 6, and 7 for the HepG2 cells and 10, 14, 3, 3, 3, for the HC-04 cells in the no treatment (NoTx), DMSO, 15, 30, and $150 \mu \mathrm{M}$ PCB126 groups, respectively.

might support that methylation anomalies predispose to cancer development, or they might be bystander effects, or some might be a consequence or cause for the spontaneous transformation process that occurred while creating the HC-04 cell line, and finally they might be long-term changes occurring over the course of multiple cell passages. In support of in situ differences, others observed that tissues adjacent to tumors are not epigenetically normal [54-56]; similar to the results of the current cell lines, RASSF1 is hypermethylated in both the hepatocarcinomas (HCC) and in adjacent tissues while GSTp1 is hypermethylated in HCC [57]. Epigenetic anomalies can also be bystander effects of the developing tumor [58]. For example, in radiation studies, altered epigenetic enzyme activities (DNA methyltransferase) is a bystander effect leading to the induction of genome instability in surrounding naïve cells [59-61]. Nevertheless, these DNA methylation differences between the three cell types offer gene targets for further epigenetic comparisons.

\subsection{HepG2 and HC-04 cell line differences in response to $5 \mathrm{adC}$}

5adC induced hypomethylation in all investigated genes. The DNA hypomethylating activity of 5adC has been known for a long time [62], as well as its ability to restore mRNA expressions of some tumor suppressor genes in HepG2 cells [63]. Here 5adC 


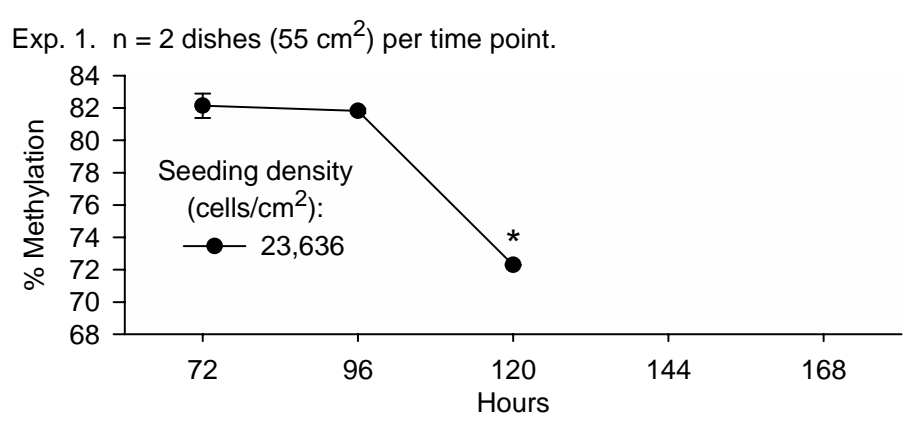

Exp. 2. $\mathrm{n}=2$ wells per time point ( 6 well plates, $9.4 \mathrm{~cm}^{2}$ per well).

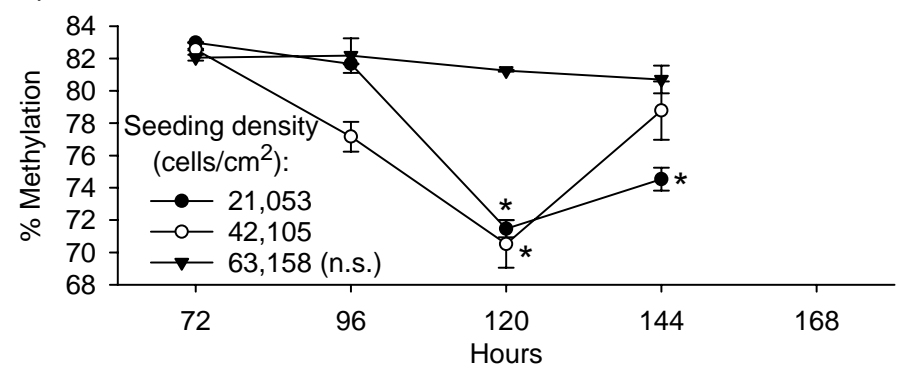

Exp. 3. $\mathrm{n}=5$ wells per time point ( 6 well plates, $9.4 \mathrm{~cm}^{2}$ per well).

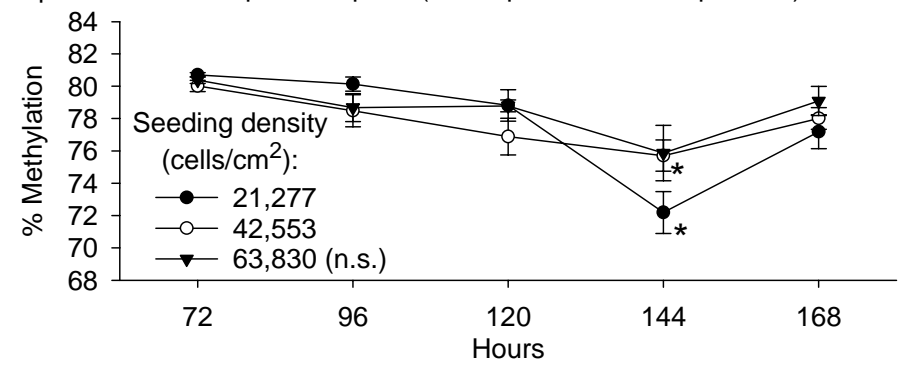

Figure 7. Effects of seeding cell density on DNA methylation through time for AluYb8 in HepG2 cells. Regardless of the culture flask, seeding HepG2 cells at low density (21,000 to 43,000 cells/ $\left.\mathrm{cm}^{2}\right)$ was associated with a drop in DNA methylation at 120-144 h after seeding. The pyrosequencing assays measured methylation abundance at five CpG sites and the average of these five sites was used here for each sample. Mean \pm s.e. *: indicates time points statistically different from the 72-h time point ( $p<0.05$ from the Dunnett's method following ANOVA on rank, or Holm-Sidak comparisons following ANOVA on data normally distributed with homogenous variances).

increased mRNA expression in 6/9 genes in the non-cancer HC-04 cell line and 3/9 genes in the cancer HepG2 cell line. The observations that 5adC-induced mRNA expression of GSTp1, RASSF1, and RUNX3 in both cell lines suggest epigenetic similarities in their regulation. In contrast, DAB2IP, DLEC1, and SOCS1 were increased only in HC-04 cells, and despite the large CCND2 methylation difference between cell lines and 5adC-induced hypomethylation, CCND2 mRNA expression remained unresponsive. The results support that the magnitude of 5adC-induced hypomethylation was not related to the magnitude of the mRNA responses, and additional mechanisms might regulate their expression. Genes are silenced by a combination of epigenetic silencing marks [64], DNA methylation being only one of them. Thus, the comparison of HepG2 and HC-04 cells provides a model to further investigate epigenetic regulatory mechanisms (e.g. histone post-translational modifications, nucleosomal positioning) across genes and hepatocyte cell types.

The literature revealed similarities and differences with the current observations. DAB2IP was previously studied by methylation-specific PCR and reported to be unmethylated in HepG2 cells [65]; in contrast 
here quantitative pyrosequencing demonstrates hypermethylation similar to the results of the ENCODE Project (Table S1 for details). The data for SOCS1 and RUNX3 were similar to the literature. SOCS1 is hypermethylated in the majority of hepatocarcinomas [reviewed in [66, 67]] and was equally hypermethylated in both cell lines. RUNX3 inactivation in cancer cells occurs mainly through DNA hypermethylation, apparently as a result of EZH2 activity [68], and its mRNA expression was found to be responsive to 5adC in both cell lines. RASSF1 and DLEC1 responded differently between cell lines despite that RASSF1 and DLEC1 are located in close chromosomal region (3p21.3 and telomeric subregion 3T) with other tumor suppressor genes [69], which provide insights for further epigenetic investigations.

In both cell lines, the 5adC-induced demethylation of the 9 cancer related genes and 4 DNA repeated elements followed a " $U$ " shaped concentrationresponse pattern. Similar observations were previously reported: lidocaine reduces methylation in MCF7 cells at low but not at high concentrations [70], radiation induces methylation changes over a narrow range of low doses but not at high doses [71], and multiple drugs induce biphasic alterations with hypomethylation preceding hypermethylation [72]. "U” shape demethylation concentration-response suggests that perhaps ECs could induce similar response patterns and thus would require to be tested over multiple concentrations for effective detection of "epigenetic disrupters". DNA methylation measurement artifacts were reported for chemicals that create DNA adducts if investigated by restriction enzyme methodologies [73], but the current authors are unaware of artifacts that could explain the "U" shape DNA methylation response to 5adC when measured by sodium bisulfite pyrosequencing.

\subsubsection{Repeated elements}

Measuring DNA methylation of DNA repeated elements is often used as a surrogate to reflect global DNA methylation [74]. Cancer development is often reported to be associated with global DNA hypomethylation, and with LINE-1 hypomethylation in patients with hepatocellular carcinomas [75]. This is consistent with the current observations that repeated elements were generally less methylated in cell lines than in the normal liver samples. Others observed that changes in DNA methylation do not have to be large to activate retrotransposons.
In MCF-10A cells, $11.5 \%$ demethylation was sufficient to induce the expression of antisense LINE-1 chimeric transcripts [6]. This is similar to the observations that relatively small changes in DNA methylation can be associated with changes in mRNA expression (Table 1). Sat- $\alpha$ showed the largest difference in methylation between normal cells and cell lines, with more than $80 \%$ methylation at CpG position-1 and -2 in the DNA from normal livers, but less than $10 \%$ methylation in both cell lines (Figure 2). Others also reported similar magnitude in methylation reduction in 23 human myeloma cell lines [10]. Sat- $\alpha$ repeats congregate in the centromere and extend to pericentromeric areas [76]. The centromere is the region of kinetochore formation ensuring proper sister-chromatid segregation during cell division [5]. The cause of satellite DNA hypomethylation was suggested to be DNMT3b4mediated reduction in DNMT3b3 activity, leading to centromeric decondensation and chromosome instability [77]. Given the large magnitude of hypomethylation observed in both cell lines, perhaps DNA hypomethylation of Sat- $\alpha$ contributed to chromosomal instability and thus the abnormal karyotype of both the HepG2 and HC-04 cell lines [36].

\subsection{Effects of PCB126}

PCB126 induced no important decline in cellular abundance but as expected, the 72-h exposure treatment was biologically potent and increased mRNA expression of many phase-1 enzymes in both cell lines. Despite the effects on phase-1 enzymes, DNA methylation of the investigated genes was found to be resistant to PCB126 except for GSTp1 in HepG2 cells. GSTp1 is often silenced by DNA methylation; it is a phase II detoxification enzyme and a member of the glutathione Stransferase gene family that can conjugate glutathione hormone (GSH) to electrophilic metabolites and reactive oxygen species [78]. The production of reactive oxygen species, a predominant feature of PCB exposure in vitro [79], was likely increased in the current experiment given the PCB126-induced increases in GSTp1 expression in both cell lines. In this case, the PCB126-induced hypomethylation of GSTp1 appeared to be associated with a solicited detoxification response rather than an oncogenic step. These observations demonstrate that levels of DNA methylation can be used to differentiate cell types, but hypermethylation of GSTp1 in HepG2 cells is not necessarily an indication of gene 
silencing. Nevertheless, the experiments with the hypomethylating drug 5adC demonstrated that DNA methylation was suppressing the expression of GSTp1 in both cell lines. Other HepG2 investigations report GSTp1 mRNA inducibility but with variable promoter methylation levels [80, 81]. The investigation of different DNA segments and regional differences in GSTp1 promoter methylation [82], as well as discordant results between DNA methylation analysis performed with different technologies [83] were reported to explain variability in GSTp1 data sets. The current contrasting methylation profile with similar GSTp1 mRNA responses between both cell lines deserve further epigenetic studies across the set of response elements present in the GSTp1 gene.

\subsection{Rethinking analysis strategy}

The number of techniques for the measurements of DNA methylation and its hydroxylated intermediates [84] is expanding but this field has not reached maturity. Batch effects [85, 86], cell culture conditions (embryonic stem cells [87, 88]), rate of cell proliferation [89], and random stochastic DNA methylation changes occurring through time [90], are factors influencing DNA methylation analyses. The current data reiterate warnings for batch effects with GSTp1 in HepG2 cells, and clearly highlight seeding density as a new confounding factor for methylation of AluYb8, but not GSTp1. These sources of variability, and the fact that most of the EC literature report induction of only subtle changes in DNA methylation [91], forces a rethinking of the technologies and model system to be used in the field of toxicology for the identification of potential "epigenetic disruptors". Perhaps DNA methylation changes are induced by ECs in small foci of cells but such potential effect is diluted by all other cells present in the culture or tissue and can mask the epimutations. Most investigations used these aggregate responses instead of cell-by-cell analyses. Finally, selection of a model in which the epigenetic system is solicited through a cellular transformation process might reveal better sensitivity to EC exposure than already transformed cell lines.

\section{CONCLUSION}

This study found different DNA methylation profiles between normal livers, the non-cancer HC-04 cells, and the HepG2 cancer cell line, and reiterates that DNA methylation in repeated elements and cancerrelated genes is cell type-specific. The DNA from
HC-04 cells, which were derived from a tissue adjacent to a hepatoma, was not epigenetically similar to the DNA of normal hepatocytes. The large differences in DNA methylation support the notion that DNA methylation has great potential for oncogenic biomarker discoveries.

Testing effects of 5adC and PCB126 revealed cell line differences in terms of labile DNA methylation sites and gene expression responses. $5 \mathrm{adC}$ induced a "U" shape dose-response hypomethylation of repeated elements and cancer gene promoters in both cell lines. These observations suggest that effects of EC on DNA methylation should be studied over detailed concentration-response ranges.

Divergence in the magnitude of 5adC-induced hypomethylation and mRNA responses, and the differences in GSTp1 methylation between both cell lines despite similar GSTp1 mRNA responses to PCB126, suggest that specific measures of methylation level are not necessarily close indications of gene functionality.

The current experiment demonstrated only subtle PCB126-induced DNA methylation changes. To exploit epigenetic changes in order to improve chemical risk assessments, a better understanding of epigenetic changes is required across functional response elements within genes to gain knowledge about their contributions to relevant mechanism and mode of action leading to adverse effects. Other sensitive experimental models are required that can generate reproducible concentration-response curves, and distinguish abnormal changes from normal variations.

Finally, the different DNA methylation patterns and gene expression responses between the non-cancer HC-04 and cancer HepG2 cell lines provide alternative models to further explore epigenetic divergence in gene expression regulation.

\section{ACKNOWLEDGEMENTS}

The authors are grateful to Dr. Guillaume Pelletier, Dr. Errol Thomson, and Dr. Nasrin Khan, for carefully reviewing this manuscript, and to Leonora Marro and Sabit Cakmak for guidance in the statistical analyses of DNA methylation data. This work was supported by funds from Health Canada's Chemicals Management Plan.

\section{CONFLICT OF INTEREST STATEMENT}

The authors have no conflict of interest to declare. 


\title{
SUPPLEMENTARY MATERIAL
}

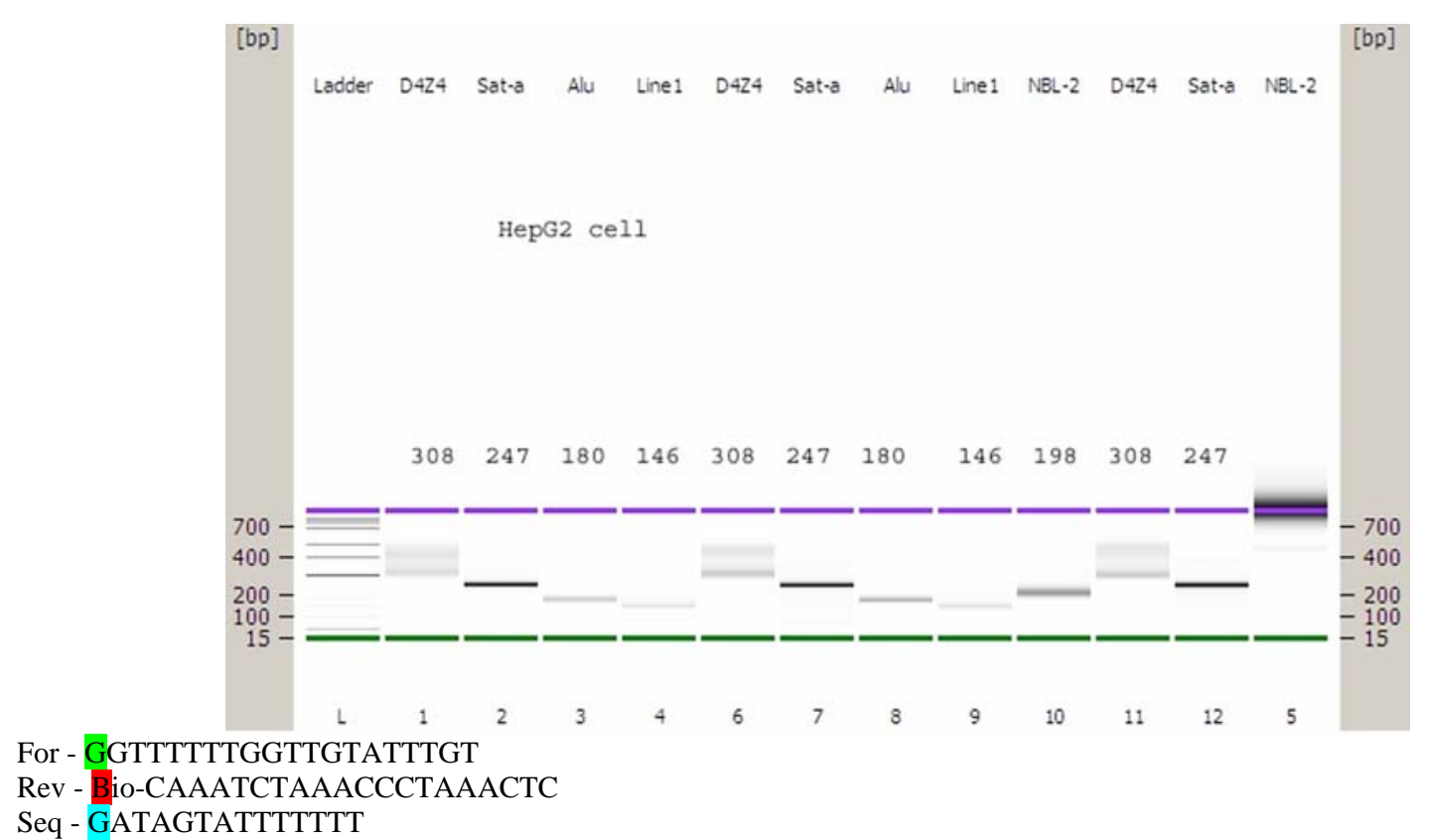

Sodium bisulfite-converted 531 nucleotide fragments with two binding sites for the reverse primer [obtained by ePCR, http://bisearch.enzim.hu [92]]:

\begin{abstract}
GGTTTTTTGGTTGTATTTGTTGTAGTGTATAGTTTGGTTGAGGTGTATGGGAGTTTGTTGGTTTTTTTTTGTTTGTGTTTGTTTGT GAAATTTTGGTTGGGGTTTATTGTGATGGTTTTTTTGATATTTTTGGATAGTATTTTTTTTGTGGAAGTTTGGGGATGAGGATG GTGATGGAGATTTGTTTGGATTTTGAGTTAAAGTGAGGTTTTGTGAGTTTGTTTTGAGTGGAATTTGTATTTGGGTATTGTTAT TAGAGAATGGTTGGTTTAGGTTATTGGTATTTTGGAGTTTAGGGTTTAGATTTGGTTTTAGAATGAGAGGTTATGTTAGTTGA GGTAGTATTGGTGGGAATTTTGGTTTTGGTTTGGGAGATGTGGTTTGTTAGAAGGTTGGTGAAAGTGGATTGTTGTTATTGGA TTTTAGATTGTTTTGTTTTTTTGAGTTTTTGAGAAGGATTGTTTTTTAGGTATTGTTGTTTGGGAGGAGTTGGTTAGAGAGATG GGTTTTTTGGAGTTTAGGATTTAGATTTG
\end{abstract}

Sodium bisulfite-converted 308 nucleotide fragment [obtained by ePCR, http://bisearch.enzim.hu [92]]:

GGTTTTTTGGTTGTATTTGTTGTAGTGTATAGTTTGGTTGAGGTGTATGGGAGTTTGTTGGTTTTTTTTTGTTTGTGTTTGTTTGT GAAATTTTGGTTGGGGTTTATTGTGATGGTTTTTTTGATATTTTTGGATAGTATTTTTTTTGTGGAAGTTTGGGGATGAGGATG GTGATGGAGATTTGTTTGGATTTTGAGTTAAAGTGAGGTTTTGTGAGTTTGTTTTGAGTGGAATTTGTATTTGGGTATTGTTAT TAGAGAATGGTTGGTTTAGGTTATTGGTATTTTG

Sequence of 542 nucleotide long fragment on chromosome 4 (gi|224589816:190988978-190989511 Homo sapiens chromosome 4 , GRCh37.p13 Primary Assembly) with two binding sites for the reverse primer and annotated target CpG sites (sequence obtained using http://www.ncbi.nlm.nih.gov/nuccore/):

GGCCTCCTGGCTGCACCTGCCGCAGTGCACAGTCCGGCTGAGGTGCACGGGAGCCCGCCGGCCTCTCTCTGCC CGCGTCCGTCCGTGAAATTCCGGCCGGGGCTCACCGCGATGGCCCTCCCGACACCCTCGGACAGCACCCTCCC $\mathrm{C}^{1} \mathrm{GC}^{2}$ GGAAGCCC ${ }^{3}$ GGGGAC $^{4}$ GAGGAC $^{5}$ GGC $^{6}$ GAC $^{7}$ GGAGACTC $^{8}$ GTTTGGACCCC $^{9}$ GAGCCAAAGCGAGGCCCTG CGAGCCTGCTTTGAGCGGAACCCGTACCCGGGCATCGCCACCAGAGAACGGCTGGCCCAGGCCATCGGCATT CCGGAGCCCAGGGTCCAGATTTGGTTTCAGAATGAGAGGTCACGCCAGCTGAGGCAGCACCGGCGGGAATCT CGGCCCTGGCCCGGGAGACGCGGCCCGCCAGAAGGCCGGCGAAAGCGGACCGCCGTCACCGGATCCCAGACC GCCCTGCTCCTCCGAGCCTTTGAGAAGGATCGCTTTCCAGGCATCGCCGCCCGGGAGGAGCTGGCCAGAGAG ACGGGCCTCCCGGAGTCCAGGATTCAGATCTG

Figure S1. Verification of amplicon sizes for DNA repeated elements in HepG2 cells.

The D4Z4 primer sets amplified two predominant amplicon bands of around 300 and 500 nucleotides in length. An example of the bioanalyzer results is shown here. In silico PCR showed potential sequences (shown below) that might generate these bands; two bisulfite converted sequences (531 and $308 \mathrm{nt}$ ) and an original sequence (542 nt) are shown with the position of the three primers, all sequences include the sequence of interest targeted by the sequence primer. A difficulty in investigating DNA repeated elements is the presence of mutations in the amplicons. D4Z4 ePCR amplicons were detected on chromosome 4, 10 and Y. 
Table S1. Pyrosequencing assays recommended by Qiagen for cancer-related genes: (A) characteristics and (B) nucleotide sequences. Nucleotide sequences of primers were proprietary. All targeted regions were within a CpG island. For all assays, amplicons from sodium bisulfite-converted DNA were produced with 45 PCR cycles using an annealing temperature (TM) of $56^{\circ} \mathrm{C}$.

\begin{tabular}{|c|c|l|}
\hline (A) Assays & GeneGlobe Cat no. & \multicolumn{1}{|c|}{ Target location } \\
\hline CCND2 & PM00051653 & Chr12: 4379380-4379530 \\
\hline DAB2IP & PM00141932 & Chr9: 124462117-124462212 \\
\hline DLEC1 & PM00104174 & Chr3: 38080705-38080790 \\
\hline EP300 & PM00199752 & Chr22: 41487320-41487419 \\
\hline FHIT & PM00017129 & Chr3: 61238986-61237112 \\
\hline GSTp1 & PM00151816 & Chr11: 67351867-67351904 \\
\hline OPCML & PM00155820 & Chr11: 132814121-132814218 \\
\hline RASSF1 & PM00013293 & Chr3: 50377772-50377955 \\
\hline RUNX3 & PM00000112 & Chr1: 25257262-25257350 \\
\hline SFRP2 & PM00018802 & Chr4: 54712645-154712755 \\
\hline SOCS1 & PM00176785 & Chr16: 11348612-11348720 \\
\hline TNFRSF10D & PM00037352 & Chr8: 23021418-23021835 \\
\hline
\end{tabular}

\begin{tabular}{|c|c|c|}
\hline \multicolumn{3}{|c|}{ (B) Nucleotide sequences } \\
\hline Assay & & Sequences \\
\hline \multirow[t]{3}{*}{ CCND2 } & $\mathrm{CpG}$ & TC $^{6}$ GC $^{5}$ GCTGCTCCC ${ }^{4}$ GGGCCTTGAGCC ${ }^{3}$ GACC $^{2}$ GC $^{1} G$ \\
\hline & Disp & GTCGTCGTCGTAGTCGATGTCAGTCGTCG \\
\hline & UCSC & $\begin{array}{l}\text { position } C^{1} \text { is part of an area shown with partial methylation in HepG2 cells and no } \\
\text { methylation in primary hepatocytes. }\end{array}$ \\
\hline \multirow[t]{3}{*}{ DAB2IP } & CpG & TC $^{1}$ GGCC $^{2}$ GGGTTTGGCC ${ }^{3}$ GAGACC $^{4}$ GGGC $^{5}$ GCTGCCC $^{6}$ GT \\
\hline & Disp & ATCGTCGTGTCGAGAGTCGTCGTCTAGATCG \\
\hline & UCSC & $\begin{array}{l}\mathrm{C}^{4}, \mathrm{C}^{5} \text {, and } \mathrm{C}^{6} \text {, are reported as methylated for HepG2 cells and primary hepatocytes; no } \\
\text { data are available for the other positions. }\end{array}$ \\
\hline \multirow[t]{3}{*}{ DLEC1 } & CpG & AC $^{1}$ GC $^{2}$ GGAGGTCTTTAGC ${ }^{3}$ GTCCC $^{4}$ GGACCAAC $^{5}$ GA \\
\hline & Disp & TATCGTCGATGCTCTTAGTCGATTCGAGTATCG \\
\hline & UCSC & $\begin{array}{l}C^{1}, C^{2} \text {, and } C^{3} \text { are partially methylated, whereas } C^{4} \text { and } C^{5} \text { are unmethylated in HepG2 } \\
\text { cells and not methylated in primary hepatocyte or liver biopsy. }\end{array}$ \\
\hline \multirow[t]{3}{*}{ EP300 } & CpG & $\mathrm{C}^{1}$ GAGGAAGGC $^{2}$ GCCAAGTC $^{3} \mathrm{GC}$ \\
\hline & Disp & GTCGAGAGTCGATAGTCG \\
\hline & UCSC & Unmethylated. \\
\hline \multirow[t]{3}{*}{ FHIT } & CpG & AGGGAGGGAGC $^{5}$ GC $^{4}$ GGGGCC $^{3}$ GGAGC $^{2}$ GCC $^{1}$ GC \\
\hline & Disp & TAGAGATGTCGTCGGTCGAGTCGTCG \\
\hline & UCSC & $\mathrm{C}^{1}, \mathrm{C}^{2}$, and $\mathrm{C}^{3}$ are unmethylated, no data for others. \\
\hline \multirow[t]{3}{*}{ GSTp1 } & CpG & CCCTCCCC $^{1}$ GGGTTGCTGC $^{2}$ GAGGC $^{3}$ GGAGTC $^{4}$ GGCCC $^{5}$ GGT \\
\hline & Disp & ATTCGTCGTCTAGTCGATGTCGAGATCGTCG \\
\hline & UCSC & No data. \\
\hline
\end{tabular}


Table S1 continued..

\begin{tabular}{|c|c|c|}
\hline \multirow[t]{3}{*}{ OPCML } & CpG & CTTCCCTC $^{1}$ GCC $^{2}$ GATGCCAGC ${ }^{3} \mathrm{GT}$ \\
\hline & Disp & ATTCGATCGAGTGTAGTCG \\
\hline & UCSC & No data \\
\hline \multirow[t]{3}{*}{ RASSF1 } & CpG & GCC $^{6}$ GC $^{5}$ GACTTGACCC ${ }^{4}$ GC $^{3}$ GGC $^{2}$ GACTGC $^{1}$ GCT \\
\hline & Disp & TGTAGTCGTCATGATCGTCGTCGTAGTCGTCG \\
\hline & UCSC & No data. \\
\hline \multirow[t]{3}{*}{ RUNX3 } & CpG & $\mathrm{GC}^{7} \mathrm{GC}^{6} \mathrm{GTC}^{5} \mathrm{GTCCAC}^{4} \mathrm{GCCC}^{3} \mathrm{GGCC}^{2} \mathrm{GGC}^{1} \mathrm{G}$ \\
\hline & Disp & ATCGTCGTCGTCGATGATCGATCGTCG \\
\hline & UCSC & $\begin{array}{l}\mathrm{C}^{1} \text { reported at } 100 \% \text { methylation in HepG2 cells and at } 50 \% \text { in primary hepatocytes. } \\
\mathrm{C}^{2} \text { is reported at } 0 \% \text { methylation in both cell types }\left(\mathrm{C}^{2} \text { is the only site from all positions of }\right. \\
\text { all genes that differ from our results). No data is provided for the other positions }\end{array}$ \\
\hline \multirow[t]{3}{*}{ SFRP2 } & CpG & $\mathrm{GC}^{7} \mathrm{GC}^{6} \mathrm{GGCACC}^{5} \mathrm{GC}^{4} \mathrm{GGC}^{3} \mathrm{GGC}^{2} \mathrm{GCCTTCAC}^{1} \mathrm{GAACCCAGAC}$ \\
\hline & Disp & TGTCTGTCGATGAGTCGTCGTCGTCGTAGTCGTCG \\
\hline & UCSC & No data. \\
\hline \multirow[t]{3}{*}{ SOCS1 } & CpG & CC $^{5}$ GGCAGC $^{4}$ GCCC $^{3}$ GCC $^{2}$ GTGCAC $^{1}$ GCAG \\
\hline & Disp & ATGTCGTCGTCATCGTCGTCGATGTCG \\
\hline & UCSC & $\begin{array}{l}\text { These CpG sites are reported as fully methylated in HepG2 cells and to be partially } \\
\text { methylated in primary hepatocytes. }\end{array}$ \\
\hline \multirow[t]{3}{*}{ TNFRSF10D } & CpG & C $^{1}$ GAGAACCTTTGCAC ${ }^{2}$ GC $^{3}$ GCACAAACTAC ${ }^{4}$ GGGGA \\
\hline & Disp & GTCGAGATTGTCATCGTCGATATAATATCG \\
\hline & UCSC & $\mathrm{C}^{1}$ to $\mathrm{C}^{3}$ unmethylated, no data for the fourth $\mathrm{CpG}$. \\
\hline
\end{tabular}

UCSC: the ENCODE project DNA methylation data obtained by Reduced Representation Bisulfite Sequencing and available in the UCSC Genome Browser are summarized here and are in agreement with our own data. The similarity between the current results and those of the ENCODE project generates confidence in the quality of the DNA methylation data for the additional CpG sites investigated here and that were not reported in the UCSC Genome Browser. EP300, FHIT, and TNFRSF10D showed levels of methylation that were below the limit of quantitation by bisulfite pyrosequencing and were excluded from further analyses.

Table S2. Pyrosequencing assays ${ }^{1}$ for DNA repeated elements and amplicon size verification.

\begin{tabular}{|c|c|c|}
\hline \multicolumn{3}{|r|}{ Nucleotide sequences } \\
\hline Assay & \multicolumn{2}{|r|}{ Sequences } \\
\hline \multirow[t]{5}{*}{ Line-1 } & Fwd & TTTTGAGTTAGGTGTGGGATATA \\
\hline & Rev & 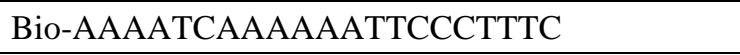 \\
\hline & Seq & AGTTAGGTGTGGGATATAGT \\
\hline & Disp & ATCAGTGTGTCAGTCAGCTTAGTCTG \\
\hline & CpG & TTC $^{1}$ GTGGTGC ${ }^{2}$ GTC $^{3}$ GTTTTTTAAGTC ${ }^{4}$ GGTTT \\
\hline \multirow[t]{5}{*}{ AluYb8 $^{2}$} & Fwd & Bio-AGATTATTTTGGTTAATAAG \\
\hline & Rev & AACTACYAACTACAATAAC $(\mathrm{Y}=\mathrm{C} / \mathrm{T})$ \\
\hline & Seq & AATAACTAAAATTACAAAC \\
\hline & Disp & CGATCGACATCGATCGATCAGACTGA \\
\hline & CpG & $\mathrm{AC}^{5} \mathrm{GCCC}^{4} \mathrm{GCCACC}^{3} \mathrm{GC}^{2} \mathrm{GCCC}^{1} \mathrm{GA}$ \\
\hline
\end{tabular}


Table S2 continued..

\begin{tabular}{|c|c|c|}
\hline \multirow[t]{5}{*}{ Sat- $\alpha$} & Fwd & AGTTTAATTTATAGAGTAGAGTAG \\
\hline & $\operatorname{Rev}$ & Bio-AАAТСТTСАСТТАСАААТАССАС \\
\hline & Seq & TGGGATTTTTTTGAGAATTT \\
\hline & Disp & ATCGTGTATCGATATTGATC \\
\hline & CpG & C $^{1}$ GTTGGAAAC ${ }^{2}$ GGGATAAATTTTAC ${ }^{3}$ G \\
\hline \multirow[t]{5}{*}{$\mathrm{D} 4 \mathrm{Z} 4^{3}$} & Fwd & GGTTTTTTGGTTGTATTTGT \\
\hline & Rev & Bio-САAАТСТАААСССТАААСТС \\
\hline & Seq & GATAGTATTTTTTT \\
\hline & Disp & $\begin{array}{l}\text { ATCTGTCGATGTCGGTATCGAGTATCAGTCGTATCGA } \\
\text { GTATCGTGTATTCGAGCTA }\end{array}$ \\
\hline & CpG & $\begin{array}{l}\text { C }^{1} \text { GC }^{2} \text { GGAAGTTC }^{3} \text { GGGGAC }^{4} \text { GAGGAC }^{5} \text { GGC }^{6} \text { GAC }^{7} \text { GGA } \\
\text { GATTC }^{8} \text { GTTTGGATTC }^{9} G\end{array}$ \\
\hline \multirow[t]{5}{*}{ NBL-2 } & Fwd & GTGGTTTGGGTTAGGTATAGA \\
\hline & Rev & Bio-ААСАСТААССААТСССАСААС \\
\hline & Seq & GTGTATGGATTTTATTTTT \\
\hline & Disp & ATCTGTTCAGTCTGTCAGTCGTGATTCGTGTATGATC \\
\hline & CpG & $\begin{array}{l}\mathrm{C}^{1} \mathrm{GTTTC}^{2} \mathrm{GTC}^{3} \mathrm{GTC}^{4} \mathrm{GTTC}^{5} \mathrm{GTTTATTTTC}^{6} \mathrm{GGTGTTATA} \\
\mathrm{C}^{7} \mathrm{G}\end{array}$ \\
\hline
\end{tabular}

1: The forward (Fwd), reverse (Rev) and sequencing primers (Seq) were from Choi et al. [3], and were designed for sodium bisulfite-converted DNA. Disp: nucleotide dispensation sequence in the instrument program. CpG: superscript numbers identify the CpG sites investigated in the target region, and reflect the $\mathrm{CpG}$ positions provided on the $\mathrm{X}$-axis of the figures in the result section. The superscript numbers are in ascending or descending orders to reflect assays targeting the sense or antisense strand. Amplicons were generated with 50 PCR cycles for each assay. The annealing temperature and accession numbers from which DNA sequences were used to design the primer sets were as follow: Line-1, $53{ }^{\circ} \mathrm{C}$, X58075; AluYb8, $58{ }^{\circ} \mathrm{C}$, U14570; Sat- $\alpha, 53{ }^{\circ} \mathrm{C}$, M38468; D4Z4, $60{ }^{\circ} \mathrm{C}, \mathrm{AF} 117653$; NBL-2, $64{ }^{\circ} \mathrm{C}, \mathrm{Y} 10752$.

2: Based on sequence homology, this assay also amplifies AluSb2 [93].

3: All assays, except that of D4Z4, generated amplicons of the appropriate size as verified by Agilent Bioanalyzer (see table S1).

Table S3. List of 84 genes investigated for mRNA abundance using the Qiagen-SABiosciences drug metabolism Phase-I enzymes PCR array kit.

Cytochrome P450 and substrate specificity:

Xenobiotics: CYP1A1, CYP1A2, CYP1B1, CYP2A6, CYP2A13, CYP2B6, CYP2C8*, CYP2C9*,

CYP2C18, CYP2C19, CYP2D6, CYP2E1, CYP2F1, CYP3A4*, CYP3A5, CYP3A7, CYP4F3*.

Steroidogenic: CYP11A1, CYP11B1, CYP11B2, CYP17A1, CYP19A1, CYP21A2.

Vitamin D: CYP24A1, CYP26C1*, CYP27A1*, CYP27B1.

Retinoic acid: CYP26A1, CYP26B1, CYP26C1*.

Bile acid: CYP27A1*, CYP3A4*, CYP7A1, CYP7B1, CYP8B1.

Fatty acids, eicosanoids: CYP2C8*, CYP2C9*, CYP4A11, CYP4B1, CYP4F2, CYP4F3*, CYP4F8, CYP4F12.

Unknown: CYP2A7, CYP2W1, CYP3A43, CYP4A22, CYP4F11. 
Table S3 continued...

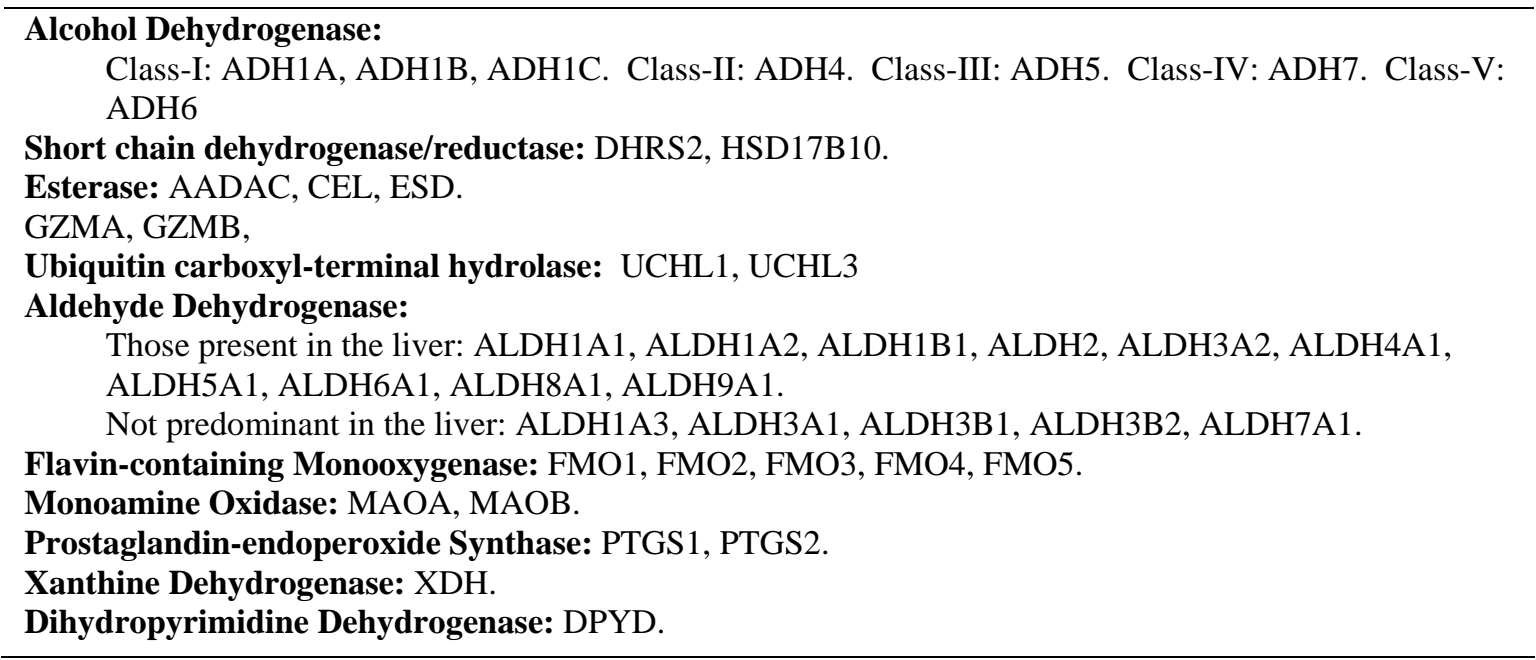

*: Some CYP are listed under more than one function and appear more than once.

\section{REFERENCES}

1. Hoffmann, M. J. and Schulz, W. A. 2005, Biochem. Cell Biol., 83, 296.

2. Aporntewan, C., Phokaew, C., Piriyapongsa, J., Ngamphiw, C., Ittiwut, C., Tongsima, S. and Mutirangura, A. 2011, PLoS One, 6, e17934.

3. Choi, S. H., Worswick, S., Byun, H. M., Shear, T., Soussa, J. C., Wolff, E. M., Douer, D., Garcia-Manero, G., Liang, G. and Yang, A. S. 2009, Int. J. Cancer, 125, 723.

4. Baylin, S. B. and Jones, P. A. 2011, Nat. Rev. Cancer, 11, 726.

5. Gonzalez-Barrios, R., Soto-Reyes, E. and Herrera, L. A. 2012, Epigenetics, 7, 3.

6. Cruickshanks, H. A. and Tufarelli, C. 2009, Genomics, 94, 397.

7. Tufarelli, C., Cruickshanks, H. A. and Meehan, R. R. 2013, Mob. Genet. Elements., 3, e26832.

8. Grandi, F. C. and An, W. 2013, Mob. Genet. Elements, 3, e25674.

9. Kaer, K. and Speek, M. 2013, Gene, 518, 231.

10. Bollati, V., Fabris, S., Pegoraro, V., Ronchetti, D., Mosca, L., Deliliers, G. L., Motta, V., Bertazzi, P. A., Baccarelli, A. and Neri, A. 2009, Carcinogenesis, 30, 1330.

11. Lehnertz, B., Ueda, Y., Derijck, A. A., Braunschweig, U., Perez-Burgos, L., Kubicek, S., Chen, T., Li, E., Jenuwein, T. and Peters, A. H. 2003, Curr. Biol., 13, 1192.
12. Peters, A. H., O'Carroll, D., Scherthan, H., Mechtler, K., Sauer, S., Schofer, C., Weipoltshammer, K., Pagani, M., Lachner, M., Kohlmaier, A., Opravil, S., Doyle, M., Sibilia, M. and Jenuwein, T. 2001, Cell, 107, 323.

13. Nishida, N., Kudo, M., Nishimura, T., Arizumi, T., Takita, M., Kitai, S., Yada, N., Hagiwara, S., Inoue, T., Minami, Y., Ueshima, K., Sakurai, T., Yokomichi, N., Nagasaka, T. and Goel, A. 2013, PLoS One, 8, e72312.

14. Eden, A., Gaudet, F., Waghmare, A. and Jaenisch, R. 2003, Science, 300, 455.

15. Collotta, M., Bertazzi, P. A. and Bollati, V. 2013, Toxicology, 307, 35.

16. Pogribny, I. P. and Rusyn, I. 2013, Adv. Exp. Med. Biol., 754, 215.

17. Cheng, T. F., Choudhuri, S. and MuldoonJacobs, K. 2012, J. Appl. Toxicol., 32, 643.

18. Ruiz-Hernandez, A., Kuo, C. C., RenteroGarrido, P., Tang, W. Y., Redon, J., Ordovas, J. M., Navas-Acien, A. and TellezPlaza, M. 2015, Clin. Epigenetics., 7, 55. DOI: 10.1186/s13148-015-0055-7.

19. Rusiecki, J. A., Baccarelli, A., Bollati, V., Tarantini, L., Moore, L. E. and BonefeldJorgensen, E. C. 2008, Environ. Health Persp., 116, 1547.

20. Kim, K. Y., Kim, D. S., Lee, S. K., Lee, I. K., Kang, J. H., Chang, Y. S., Jacobs, D. R., Steffes, M. and Lee, D. H. 2010, Environ. Health Perspect., 118, 370. 
21. Chen, J., Liufu, C., Sun, W., Sun, X. and Chen, D. 2010, Toxicol. Lett., 192, 431.

22. Stel, J. and Legler, J. 2015, Endocrinology, 156, 3466.

23. Brocato, J. and Costa, M. 2013, Crit. Rev. Toxicol., 43, 493.

24. Tajuddin, S. M., Amaral, A. F., Fernandez, A. F., Rodriguez-Rodero, S., Rodriguez, R. M., Moore, L. E., Tardon, A., Carrato, A., Garcia-Closas, M., Silverman, D. T., Jackson, B. P., Garcia-Closas, R., Cook, A. L., Cantor, K. P., Chanock, S., Kogevinas, M., Rothman, N., Real, F. X., Fraga, M. F. and Malats, N. 2013, Environ. Health Perspect., 121, 650.

25. Zhang, Y., Yang, R., Burwinkel, B., Breitling, L. P. and Brenner, H. 2014, Environ. Health Perspect., 122, 131.

26. Hamm, C. A., Xie, H., Costa, F. F., Vanin, E. F., Seftor, E. A., Sredni, S. T., Bischof, J., Wang, D., Bonaldo, M. F., Hendrix, M. J. and Soares, M. B. 2009, PLoS One, 4, e8340.

27. Chappell, G., Pogribny, I. P., Guyton, K. Z. and Rusyn, I. 2016, Mutat. Res. Rev. Mutat. Res., 768, 27.

28. Robertson, L. W. and Hansen, L. G. 2001, PCBs: Recent Advances in Environmental Toxicology and Health Effects. Lexington, Kentucky, USA, The University Press of Kentucky.

29. Sun, J., Pan, L., Tsang, D. C., Zhan, Y., Liu, W., Wang, X., Zhu, L. and Li, X. 2016, Chemosphere, 163, 422.

30. Bechaux, C., Zeilmaker, M., Merlo, M., Bokkers, B. and Crepet, A. 2014, Regul. Toxicol. Pharmacol., 70, 261.

31. Strathmann, J., Schwarz, M., Tharappel, J. C., Glauert, H. P., Spear, B. T., Robertson, L. W., Appel, K. E. and Buchmann, A. 2006, Toxicol. Sci., 93, 34.

32. Consonni, D., Sindaco, R. and Bertazzi, P. A. 2012, Environ. Int., 44, 151.

33. van den Berg, M., Birnbaum, L. S., Denison, M., De Vito, M., Farland, W., Feeley, M., Fiedler, H., Hakansson, H., Hanberg, A., Haws, L., Rose, M., Safe, S., Schrenk, D., Tohyama, C., Tritscher, A., Tuomisto, J., Tysklind, M., Walker, N. and Peterson, R. E. 2006, Toxicol. Sci., 93, 223.
34. van Ede, K. I., Aylward, L. L., Andersson, P. L., van den Berg, M. and van Duursen, M. B. 2013, Toxicol. Lett., 220, 294.

35. Jacobs, M. N., Colacci, A., Louekari, K., Luijten, M., Hakkert, B. C., Paparella, M. and Vasseur, P. 2016, ALTEX, 33, 359.

36. Sattabongkot, J., Yimamnuaychoke, N., Leelaudomlipi, S., Rasameesoraj, M., Jenwithisuk, R., Coleman, R. E., Udomsangpetch, R., Cui, L. and Brewer, T. G. 2006, Am. J. Trop. Med. Hyg., 74, 708.

37. Stresemann, C., Brueckner, B., Musch, T., Stopper, H. and Lyko, F. 2006, Cancer Res., 66, 2794.

38. Datta, J., Ghoshal, K., Denny, W. A., Gamage, S. A., Brooke, D. G., Phiasivongsa, P., Redkar, S. and Jacob, S. T. 2009, Cancer Res., 69, 4277.

39. Lim, P. L., Tan, W., Latchoumycandane, C., Mok, W. C., Khoo, Y. M., Lee, H. S., Sattabongkot, J., Beerheide, W., Lim, S. G., Tan, T. M. and Boelsterli, U. A. 2007, Toxicol. In Vitro, 21, 1390.

40. Desaulniers, D., Leingartner, K., Zacharewski, T. and Foster, W. G. 1998, Toxicol. In Vitro, 12, 409.

41. Rorabacher, D. B. 1991, Anal. Chem., 63, 139.

42. Ordway, J. M., Bedell, J. A., Citek, R. W., Nunberg, A., Garrido, A., Kendall, R., Stevens, J. R., Cao, D., Doerge, R. W., Korshunova, Y., Holemon, H., McPherson, J. D., Lakey, N., Leon, J., Martienssen, R. A. and Jeddeloh, J. A. 2006, Carcinogenesis, 27, 2409.

43. Dejeux, E., El-Abdalaoui, H., Glynne Gut, I. and Tost, J. 2009, Identification and quantification of differentially methylated loci by the pyrosequencing ${ }^{\mathrm{TM}}$ technology; In J. Tost (Ed.): DNA Methylation: Methods And Protocols. NewYork, Humana Press, 189-205.

44. Potapova, A., Albat, C., Hasemeier, B., Haeussler, K., Lamprecht, S., Suerbaum, S., Kreipe, H. and Lehmann, U. 2011, BMC. Biotechnol., 11, 6.

45. Desaulniers, D., Xiao, G. H. and CummingsLorbetskie, C. 2013, Toxicology, 308C, 20.

46. ENCODE Project Consortium. 2012, Nature, 489, 57.

47. SAS Institute Inc.: Standard least squares: Random effects; JMP Statistics and Graphics Guide, Version 5. Cary, NC, USA, SAS Institute Inc., 2002, 251-265. 
48. Conover, W. J. and Iman, R. L. 1981, The American Statistician, 35, 124.

49. Karimi, M., Johansson, S. and Ekstrom, T. J. 2006, Epigenetics, 1, 45.

50. Penter, L., Maier, B., Frede, U., Hackner, B., Carell, T., Hagemeier, C. and Truss, M. 2015, Target. Oncol., 10, 523.

51. Vezina, C. M., Walker, N. J. and Olson, J. R. 2004, Environ. Health Perspect., 112, 1636.

52. Warner, M., Mocarelli, P., Brambilla, P., Wesselink, A., Patterson, D. G. Jr., Turner, W. E. and Eskenazi, B. 2014, J. Expo. Sci. Environ. Epidemiol., 24, 588.

53. Bernert, J. T., Turner, W. E., Patterson, D. G. Jr. and Needham, L. L. 2007, Chemosphere, 68, 824.

54. Wolff, E. M., Byun, H. M., Han, H. F., Sharma, S., Nichols, P. W., Siegmund, K. D., Yang, A. S., Jones, P. A. and Liang, G. 2010, PLoS Genet., 6, e1000917.

55. Lambert, M. P., Ancey, P. B., Esposti, D. D., Cros, M. P., Sklias, A., Scoazec, J. Y., Durantel, D., Hernandez-Vargas, H. and Herceg, Z. 2015, Clin. Epigenetics, 7, 15.

56. Yan, P. S., Venkataramu, C., Ibrahim, A., Liu, J. C., Shen, R. Z., Diaz, N. M., Centeno, B., Weber, F., Leu, Y. W., Shapiro, C. L., Eng, C., Yeatman, T. J. and Huang, T. H. 2006, Clin. Cancer Res., 12, 6626.

57. Qu, Z., Jiang, Y., Li, H., Yu, D. C. and Ding, Y. T. 2015, Oncol. Lett., 10, 2553.

58. Sawan, C., Vaissiere, T., Murr, R. and Herceg, Z. 2008, Mutat. Res., 642, 1.

59. Mothersill, C. and Seymour, C. 2012, Front Genet., 3, 74.

60. Rugo, R. E., Mutamba, J. T., Mohan, K. N., Yee, T., Chaillet, J. R., Greenberger, J. S. and Engelward, B. P. 2011, Oncogene, 30, 751.

61. Armstrong, C. A., Jones, G. D., Anderson, R., Iyer, P., Narayanan, D., Sandhu, J., Singh, R., Talbot, C. J. and Tufarelli, C. 2012, Epigenetics, 7, 892.

62. Karahoca, M. and Momparler, R. L. 2013, Clin. Epigenetics, 5, 3.

63. Li, Z., Zhang, H., Yang, J., Hao, T. and Li, S. 2012, Cell Biol. Int., 36, 427.

64. Mossman, D. and Scott, R. J. 2011, PLoS One, 6, e23127.
65. Qiu, G. H., Xie, H., Wheelhouse, N., Harrison, D., Chen, G. G., Salto-Tellez, M., Lai, P., Ross, J. A. and Hooi, S. C. 2007, J. Hepatol., 46, 655.

66. Sasi, W., Sharma, A. K. and Mokbel, K. 2014, Mol. Biol. Int., 2014, 630797.

67. Kazi, J. U., Kabir, N. N., Flores-Morales, A. and Ronnstrand, L. 2014, Cell Mol. Life Sci., 71, 3297.

68. Tang, B., Du, J., Li, Y., Tang, F., Wang, Z. and He, S. 2014, Med. Oncol., 31, 271.

69. Qiu, G. H., Salto-Tellez, M., Ross, J. A., Yeo, W., Cui, Y., Wheelhouse, N., Chen, G. G., Harrison, D., Lai, P., Tao, Q. and Hooi, S. C. 2008, J. Hepatol., 48, 433.

70. Lirk, P., Berger, R., Hollmann, M. W. and Fiegl, H. 2012, Br. J. Anaesth., 109, 200.

71. Bernal, A. J., Dolinoy, D. C., Huang, D., Skaar, D. A., Weinhouse, C. and Jirtle, R. L. 2013, FASEB J., 27, 665.

72. Nyce, J. 1989, Cancer Res., 49, 5829.

73. Sadikovic, B., Andrews, J. and Rodenhiser, D. I. 2007, Toxicol. Appl. Pharmacol., 225, 300.

74. Weisenberger, D. J., Campan, M., Long, T. I., Kim, M., Woods, C., Fiala, E., Ehrlich, M. and Laird, P. W. 2005, Nucleic Acids Res., 33, 6823.

75. Gao, X. D., Qu, J. H., Chang, X. J., Lu, Y. Y., Bai, W. L., Wang, H., Xu, Z. X., An, L. J., Wang, C. P., Zeng, Z. and Yang, Y. P. 2014, Liver Int., 34, 136.

76. Schueler, M. G., Higgins, A. W., Rudd, M. K., Gustashaw, K. and Willard, H. F. 2001, Science, 294, 109.

77. Kanai, Y. and Hirohashi, S. 2007, Carcinogenesis, 28, 2434.

78. Schnekenburger, M., Karius, T. and Diederich, M. 2014, Front Pharmacol., 5, 170.

79. Lin, C. H. and Lin, P. H. 2006, Chem. Biol. Interact., 162, 181.

80. Niu, D., Zhang, J., Ren, Y., Feng, H. and Chen, W. N. 2009, Mol. Oncol., 3, 67.

81. Nishinaka, T., Ichijo, Y., Ito, M., Kimura, M., Katsuyama, M., Iwata, K., Miura, T., Terada, T. and Yabe-Nishimura, C. 2007, Toxicol. Lett., 170, 238.

82. Jain, S., Chen, S., Chang, K. C., Lin, Y. J., Hu, C. T., Boldbaatar, B., Hamilton, J. P., Lin, S. Y., Chang, T. T., Chen, S. H., Song, W., Meltzer, S. J., Block, T. M. and Su, Y. H. 2012, PLoS One, 7, e35789. 
83. Alnaes, G. I., Ronneberg, J. A., Kristensen, V. N. and Tost, J. 2015, Genes (Basel), 6, 878.

84. Thomson, J. P., Hunter, J. M., Lempiainen, H., Muller, A., Terranova, R., Moggs, J. G. and Meehan, R. R. 2013, Nucleic Acids Res., 41, 5639.

85. Soriano-Tarraga, C., Jimenez-Conde, J., Giralt-Steinhauer, E., Ois, A., RodriguezCampello, A., Cuadrado-Godia, E., Fernandez-Cadenas, I., Montaner, J., Lucas, G., Elosua, R. and Roquer, J. 2013, PLoS One, 8, e60750.

86. Byun, H. M., Colicino, E., Trevisi, L., Fan, T., Christiani, D. C. and Baccarelli, A. A. 2016, J. Am. Heart Assoc., 5, e003218.

87. Bentivegna, A., Miloso, M., Riva, G., Foudah, D., Butta, V., Dalpra, L. and Tredici, G. 2013, Stem Cells Int., 2013, 192425.
88. McEwen, K. R., Leitch, H. G., Amouroux, R. and Hajkova, P. 2013, Biochem. Soc. Trans., 41, 711.

89. Goodman, J. I. and Counts, J. L. 1993, Environ. Health Perspect., 101(Suppl. 5), 169.

90. Landan, G., Cohen, N. M., Mukamel, Z., Bar, A., Molchadsky, A., Brosh, R., Horn-Saban, S., Zalcenstein, D. A., Goldfinger, N., Zundelevich, A., Gal-Yam, E. N., Rotter, V. and Tanay, A. 2012, Nat. Genet., 44, 1207.

91. Leenen, F. A., Muller, C. P. and Turner, J. D. 2016, Clin. Epigenetics, 8, 92.

92. Aranyi, T. and Tusnady, G. E. 2007, Methods Mol. Biol., 402, 385.

93. Weisenberger, D. J., Campan, M., Long, T. I., Kim, M., Woods, C., Fiala, E., Ehrlich, M. and Laird, P. W. 2005, Nucleic Acids Res., 33, 6823. 